Post print of: Peluffo, Hugo et al. "BBB-targeting, protein-based nanomedicines for drug and nucleic acid delivery to the CNS" in Biotechnology Advances, Volume 33, Issue 2, March-April 2015, Pages 277-287. The final version is available at https://doi.org/10.1016/j.biotechadv.2015.02.004

\title{
4BBB-targeting, protein-based nanomedicines for drug 5and nucleic acid delivery to the CNS
}

\section{6 \\ 7}

8Hugo Peluffo 1, 2, Ugutz Unzueta 3, 4, 5, Luciana Negro 1, 2, Zhikun $\mathrm{Xu}{ }^{3,4,5}$, 9Esther Váquez ${ }^{3,4,5}$, Neus Ferrer-Miralles ${ }^{3,4,5 *}$ and Antonio Villaverde ${ }^{3,4,5 *}$

$11^{l}$ Neuroinflammation and Gene Therapy Laboratory, Institut Pasteur de 12Montevideo, Montevideo, Uruguay

13 ${ }^{2}$ Departamento de Histología y Embriología, Facultad de Medicina, 14Universidad de la República (UDELAR), Montevideo, Uruguay

$15^{3}$ Institut de Biotecnologia $i$ de Biomedicina, Universitat Autònoma de 16Barcelona, Bellaterra, 08193 Barcelona, Spain

$17^{4}$ Department de Genètica $i$ de Microbiologia, Universitat Autònoma de 18Barcelona, Bellaterra, 08193 Barcelona, Spain

$19^{5}$ CIBER en Bioingeniería, Biomateriales y Nanomedicina (CIBER-BBN), 20Bellaterra, 08193 Barcelona, Spain

21

22* Corresponding authors 


\section{Abstract}

24The increasing incidence of diseases affecting the central nervous system 25(CNS) demands the urgent development of efficient drugs. While many of 26these medicines are already available, the Blood Brain Barrier and to a lesser 27extent, the Blood Spinal Cord Barrier pose physical and biological limitations 28to their diffusion to reach target tissues. Therefore, efforts are needed not only 29to address drug development but specially to design suitable vehicles for 30delivery into the CNS through systemic administration. In the context of the 31 functional and structural versatility of proteins, recent advances in their 32biological fabrication and a better comprehension of the physiology of the $33 \mathrm{CNS}$ offer a plethora of opportunities for the construction and tailoring of plain 34nanoconjugates and of more complex nanosized vehicles able to cross these 35barriers. We revise here how the engineering of functional proteins offer drug 36delivery tools for specific CNS diseases and more transversally, how proteins 37 can be engineered into smart nanoparticles or 'artificial viruses' to afford 38 therapeutic requirements through alternative administration routes.

\section{9}

40

41Keywords: Nanoparticles; BBB; Protein engineering; Recombinant proteins; 42Artificial viruses; Drug delivery; Gene therapy 


\section{Introduction}

45 The maintenance of the central nervous system (CNS) homeostasis is 46essential for its normal function. The limits of the CNS tissue are established 47 by the astrocytic glia limitans facing the meninges and the blood vessels, and 48by the ependimocytes of the choroid plexus were the cerebrospinal fluid is 49produced (Figure $1 \mathrm{~A}$ ). Astrocyte end-feet wrap the meningeal fibroblasts and 50the endothelial cells (ECs) of the capillaries, leaving between them the 51 basement membrane. Brain capillaries display a large surface area $\left(\sim 20 \mathrm{~m}^{2}\right.$ 52 per $1.3 \mathrm{~kg}$ brain), and thus possess a predominant role in regulating the brain 53 microenvironment. The blood-brain-barrier (BBB) limits the entry of blood54derived molecules and circulating leukocytes, protecting the CNS from 55fluctuations in plasma compositions or circulating agents such as 56neurotransmitters and xenobiotics. It is composed of specialized ECs held 57 together by multiprotein complexes known as tight junctions, astrocytes, 58pericytes and basement membrane (Abbott et al. 2006; Reese and Karnovsky 591967) (Figure 1 B). CNS ECs display more efficient cell-to-cell tight junctions 60than other ECs (Wolburg and Lippoldt 2002), rest on a continuous basement 61 membrane and express a series of transporters responsible for the regulated 62 exchange of nutrients and toxic products. These characteristics make the 63CNS ECs a continuous and selective physical barrier for hydrophilic 64 substances, and a key player in the regulated trafficking of molecules into the 65CNS (Abbott et al. 2006) (Figure 2). Interestingly, the Blood Spinal Cord 66Barrier (BSCB) displays similarities to the $\mathrm{BBB}$, but it also has some unique 67properties, among them being slightly more permeable (Bartanusz et al. 682011). Transit restrictions imposed by the BBB (and at lesser extent by BSCB) 69represent the most important barrier to overcome in the drug delivery to the $70 \mathrm{CNS}$. In the context of emerging neurological diseases, targeting drugs to the $71 \mathrm{CNS}$ is under strong pushing demands, but vehicles for BBB crossing are still 72in their infancy, with a long run until full tailoring.

\section{3}

\section{Cross-transportation through BBB}

75 The BBB gradually develops in humans during the first postnatal year 76(Adinol 1979) and its nearly complete in rats after the second postnatal week 77(Stewart and Hayakawa 1987). This highly differentiated EC phenotype is 78induced and maintained in the long term by interactions with the surrounding 
79 cells, mainly astrocytes and pericytes but also perivascular macrophages and 80even neurons (Abbott et al. 2006; Alvarez et al. 2011; Arthur et al. 1987; 81Janzer and Raff 1987). For instance, in vivo, astrocytes secrete Sonic 82Hedgehog (Shh), that will act on endothelial cells and promote BBB integrity 83(Alvarez et al. 2011). In addition to the role in long-term barrier induction and 84maintenance, astrocytes and other cells can release chemical factors that 85modulate local endothelial permeability over a time-scale of seconds to 86minutes. Thus, both natural stimuli for BBB leakage and pharmacological 87 compounds acting on endogenous BBB induction pathways like Shh inhibitors 88(Alvarez et al. 2011) can be used to transiently increase the entrance of 89 molecules into the CNS parenchyma. Moreover, the phenotypical 90characteristics of the BBB ECs includes both uptake mechanisms (e.g. GLUT911 glucose carrier, L1 amino acid transporter, transferrin receptor) and efflux 92transporters (e.g. P-glycoprotein), and thus transporter/receptor-mediated 93transit across the BBB has also been used to deliver molecules of 94pharmacological interest into the CNS parenchyma (Figure 2). In this case, 95specific transcellular receptor-mediated transcytosis transport molecules from 96the luminal membrane, lining the internal surface of the vessels, to the 97abluminal membrane on the external CNS-lining surface. In addition, less 98specific adsorptive-mediated transcytosis can also be used for the delivery of 99molecules, but CNS ECs show a lower rate of transcytosis activity than 100peripheral ECs (Rubin and Staddon 1999), making this a less efficient 101 process for the incorporation of circulating molecules.

102 A final consideration regarding potential limiting steps for the delivery of 103hydrophilic substances into the CNS across the BBB is that both intracellular 104and extracellular enzymes provide an additional barrier. Extracellular enzymes 105such as peptidases and nucleotidases are capable of metabolizing peptides 106and ATP respectively. Intracellular enzymes, that are involved in hepatic drug 107metabolism, have been found in the small microvessels from brain, the 108choroid plexuses, and the leptomeninges (pia plus arachnoid mater), such as 109monoamine oxidase and cytochrome P450, and they can inactivate many 110lipophilic neuroactive and toxic compounds (el-Bacha and Minn 1999).

111 The delivery of substances across the Blood Cerebrospinal Fluid 112Barrier (BCFB) may also be considered as an interesting option. This barrier 
113shows a morphological correlate with the $\mathrm{BBB}$ at the level of tight junctions 114between the cells. These, however, are not located at the ECs capillaries that 115are in fact fenestrated (Figure $1 \mathrm{C}$ ), but on the apical surface of the epithelial 116 cells of the choroid plexus and the arachnoid fibroblasts along the blood 117vessels, inhibiting paracellular diffusion of hydrophilic molecules across this 118barrier. When a substance reaches the cerebrospinal fluid it can diffuse 119through the Virchow-Robin's perivascular spaces (Bechmann et al. 2001), 120 which are located between the basement membrane around pericytes and $121 \mathrm{ECs}$ and the basement membrane at the surface of the glia limitans of the 122brain vessels (Figure $1 \mathrm{~B}$ ). These perivascular spaces are in direct contact 123with the subarachnoid space and thus with the cerebrospinal fluid. When 124 small tracers are injected into the cerebrospinal fluid they follow the fluids flow 125through the perivascular spaces and the ventricles, and they may enter the 126brain parenchyma (Iliff et al. 2012). In fact, after an intracisternal injection, 127small hydrophilic molecules can be observed around the ventricle walls and 128the superficial layers of the CNS in contact with the meninges or in the whole 129brain parenchyma depending on the size of the molecule (Iliff et al. 2012). 130Larger molecules will not enter the brain parenchyma after intraventricular or 131 intracisternal injection due to the ependymocytes and the glia limitans and its 132basal lamina (Bechmann et al. 2001; Iliff et al. 2012; Kim et al. 2006), being 133only observed in the perivascular compartment. Thus, after intravenous 134administration, a hydrophilic drug will not reach the cerebrospinal fluid, but if 135administered intracisternaly it may enter the brain parenchyma in a size136depending fashion. The engineering of appropriate vehicles for cargo drug 137 delivery using these administration routes may be useful to envisage potential 138therapeutic strategies.

139

1403. Disturbed BBB permeability

141 BBB disruption is a central and early characteristic of many acute and 142chronic CNS injuries such as stroke, trauma, inflammatory and infectious 143processes, Multiple Sclerosis, Alzheimer, Parkinson, epilepsy, pain, and brain 144tumors (Abbott et al. 2006; Rosenberg 2012). In these cases, the increase in 145BBB permeability is linked to the dysfunction of the CNS (Rosenberg 2012). 146For instance, inflammation is a common feature of both chronic and acute $147 \mathrm{CNS}$ injuries and it is one of the main causes of the expansion of the 
148neuropathology to adjacent CNS tissue areas. Many inflammatory mediators, 149like tumor necrosis factor- $\alpha(\mathrm{TNF} \alpha)$, induce BBB permeability acting directly 150on ECs (Deli et al. 1995) or indirectly by activating astrocytes to secrete other 151 proinflammatory mediators like IL-1 $\beta$ (Didier et al. 2003), and in this way 152contribute to the disease severity. In the Multiple Sclerosis model termed 153Experimental Allergic Encephalomyelitis (EAE), the major BBB disruption 154 occurs in white matter post-capillary venules in response to inflammatory 155stimuli (Tonra 2002), showing that these locations can also constitute 156important places for the entry of circulating molecules and cells into the brain. 157After a traumatic brain injury there is a rapid extravasation of blood in the 158central damaged areas, and intravascular coagulation and significant 159reduction in blood flow in the pericontusional brain areas. This is followed by 160two peaks of BBB opening at 4-6 hours and 2-3 days after the insult 161(Chodobski et al. 2011). Thus, though the extent and particular moments of 162BBB permeability varies in the different pathologies, it can be used as a 163therapeutic time-window to deliver molecules into the CNS (Rosenberg 2012). 164 Transient pharmacological stimulation of BBB opening for drug delivery 165is tempting, and it can be achieved by the injection of hypertonic solutions 166with Mannitol. However, the potential toxic effects, especially under 167pathological conditions, are notable. Though the permeability of the BBB may 168be spontaneously enhanced at certain time-windows post-injury, as for 169example after Traumatic Brain or Spinal Cord Injury (Bartanusz et al. 2011), 170that will allow the desired drugs entering the CNS, the pharmacological 171disruption of the $\mathrm{BBB}$ under pathological conditions may in contrast worsen 172the disease progression. For instance, the pharmacological disruption of the 173BBB enhanced the clinical severity in an EAE model (Alvarez et al. 2011), 174indicating that the integrity of the $\mathrm{BBB}$ is involved in the pathology and it also 175 modulates the recovery. In this context, the dysfunction of the BBB and BSCB 176has been well documented in the etiology or progression of several CNS 177pathologies (Bartanusz et al. 2011), making the enhancement of BBB barrier 178permeability not indicated for the delivery of drugs into the damaged CNS. 179Again, specific BBB crossing vehicles would be required to provide the drugs 180 with CNS transit properties. 
1824. Viral and viral-based vectors for BBB crossing

183 Recent reports have demonstrated that some non-pathogenic, single184stranded DNA human parvoviruses, in particular the adeno-associated virus 185(AAV) serotypes 6 and 9, enter the CNS following intravenous (i.v.) 186administration without the use of any BBB-permeabilizing agents (Duque et al. 1872009; Foust et al. 2009; Foust et al. 2010; Towne et al. 2008). This 188observation generated important expectations regarding the identification of 189surface protein motifs capable of inducing transport of vectors across the 190BBB.

191 Recombinant vectors for AAV-derived gene therapy (rAAVs) can infect 192a broad range of both dividing and post-mitotic cells, and their DNA persists in 193an episomal state thus enabling efficient and stable transduction (Grieger and 194Samulski 2005; Mandel et al. 2006). These vehicles are highly efficient in the 195nervous system and infect mainly neurons by intrathecal (Federici et al. 2012) 196or intracerebral injections (Burger et al. 2005; Mandel et al. 2006; McCown 1972005). Towne and colleagues (Towne et al. 2008) observed that motor 198neurons could be transduced along the entire spinal cord through a single 199noninvasive i.v. delivery of rAAV6 in 42 days old wt and SOD1 G93A 200transgenic mice model of Amyotrophic Lateral Sclerosis. The transduction of 201 astrocytes and other non-motor neuron cells, along with the finding that the 202motor neurons were not transduced following intramuscular injection, 203suggested that the mechanism of transduction was independent of retrograde 204transport, and that the vector was in fact able to cross the BBB (Towne et al. 2052008). Moreover, rAAV9 were found to be very efficient for transducing spinal 206cord cells including motor neurons after i.v. delivery in both neonate and adult 207mice (Duque et al. 2009). Kaspar and colleagues (Foust et al. 2009) have 208demonstrated that delivery of rAAV9 through the systemic circulation lead to 209widespread transduction of the neonatal and adult mice brain, with marked 210differences in cell tropism in relation to the stage of development and 211 complexity of the BBB (Foust et al. 2009; Lowenstein 2009). In accordance, 212Gray and colleagues (Gray et al. 2011) reported the ability of rAAV9 to 213transduce neurons and glia in the brain and spinal cord of adult mice and 214nonhuman primates. They suggest that AAV9 enters the nervous system by 215an active transport mechanism across the BBB rather than by passive slipping 
216through the tight junctions between endothelial cells, as the co-administration 217of mannitol prior to rAAV injection resulted in only a $50 \%$ increase in brain 218delivery. They observed extensive transduction of neurons and glia throughout 219the mice brain and spinal cord (with neurons outnumbering astrocytes $\sim 2: 1$ in 220the hippocampus and striatum and 1:1 in the cortex). However, the overall 221 transduction efficiency was considerably lower in non-human primates, being 222glial cells the main cell type transduced. These rodent/non-human primate 223differences are important for clinical applications, and may reflect a variety of 224species-specific factors including differential BBB transport, capsid-interacting 225 blood factors to promote or inhibit rAAV9 transduction, neural cell tropism 226within the brain, and/or intracellular trafficking and vector persistence. A 227summary of the AAV9 viral-based administration strategies to cross the BBB 228for therapeutic purposes is summarized in Figure 3. Nevertheless, the 229identification of the functional motifs of the surface proteins of AVV6 and AVV9 230 will surely contribute to the engineering of more effective vectors for the 231 treatment of central nervous system injuries. In fact, AAV capsid DNA shuffling 232and subsequent directed evolution generated AVV novel clones able to cross 233selectively the seizure-compromised BBB after i.v. administration (Gray et al. 2342010).

236 Obviously, in the context of biological risks associated to administration 237of viruses (Edelstein et al. 2007) and the inflammatory conditions linked to 238AVV administration and immune responses (Daya and Berns 2008), 239molecular carriers or non-infectious virus-inspired constructs (artificial viruses) 240would be preferred for drug BBB-cross delivery. Artificial viruses are 241 nanostructured, manmade molecular oligomers that mimic viral behaviour 242regarding cell penetrability, targeted delivery of associated drugs and nucleic 243acids and other key functions relevant to encapsulation, cell surface receptor 244targeting, intracellular trafficking and eventual nuclear delivery, among others 245(Mastrobattista et al. 2006). In this regard, peptides and proteins are enough 246versatile to functionalize these vehicles, or the drug itself in simpler 247nanoconjugates. When the building blocks of drug carries are proteins, these 248functions can be recruited by the incorporation, in a single polypeptide chain, 249of functional peptides from diverse origins that supply desired biological 
250activities to the whole construct (Ferrer-Miralles et al. 2008; Neus Ferrer251Miralles et al. 2013; Vazquez et al. 2008; Vazquez et al. 2009). Also, principles 252 for the rational control of self-assembling of natural and fully de novo 253designed polypeptides as nanostructured materials are being established 254(Domingo-Espin et al. 2011; Unzueta et al. 2012a; Unzueta et al. 2012b; 255Unzueta et al. 2013; Vazquez et al. 2010; Vazquez and Villaverde 2010), thus 256opening a plethora of possibilities for the design and biological production of 257nanostructured, protein-based artificial viruses (Neus Ferrer-Miralles et al. 2582013; Rodriguez-Carmona and Villaverde 2010; Vazquez and Villaverde 2592013) with good clinical grade formulation profile. The BBB-crossing abilities 260 of AAVs prove, in any case, the potential penetrability of nanosized protein 261 entities in the context of emerging nanomedicines of CNS.

262

\section{BBB-crossing protein tags in artificial drug carriers}

264 From a different angle, chemical modification of a drug can enhance its 265penetrability into the CNS, for example by adding domains for glycosylation 266(Poduslo and Curran 1992), methylation (Hansen, Jr. et al. 1992) and 267pegylation (Witt et al. 2001), lipophilic domains (Egleton and Davis 2005), or 268coating it with polysorbates (Bhaskar et al. 2010). Also, precursors can cross 269the BBB when the drug cannot, as is the case of L- Dopa in the treatment of 270Parkinson's disease (Wade and Katzman 1975). In a very different context, 271 adequate engineering of natural proteins can offer, at different extents, tools to 272 functionalize free drugs or nanosized carriers to reach the CNS parenchyma 273(Table 1). For that, receptor-mediated transcytosis can be reached by the 274incorporation of proteins or short peptides that act as ligands of insulin, 275transferrin or low density lipoprotein receptors (Table 1). For instance, 276monoclonal antibodies covalently bound to therapeutic proteins have been 277 targeted to insulin and transferrin receptors (TfRs) in both in vitro and in vivo 278models ( $\mathrm{Fu}$ et al. 2010b; Fu et al. 2011; Lu et al. 2011). In these experiments, 279recombinant proteins have two functional moieties; the therapeutic peptide 280 fused to the carboxy terminus of the IgG heavy chain and the complementarily 281 determining regions of the monoclonal antibodies that are located at the $\mathrm{N}$ 282terminus (Pardridge and Boado 2012). This delivery platform, dubbed 283Molecular Trojan Horse and extensively exploited by Pardridge's group 
284(Pardridge 2006), can be adapted to any therapeutic protein as long as its 285production in recombinant organisms maintains its biological function. In this 286context, recent insights in industrial-oriented metabolic engineering (Lee et al. 2872012) and the wide diversity of microbial species that are now under 288exploration as cell factories for therapeutic proteins (Corchero et al. 2013), 289offer alternatives to conventional hosts for the production of highly functional 290 protein species. In addition, monoclonal antibodies conjugated to polymeric 291micelles (Yue et al. 2012), liposomes (Mamot et al. 2005; Schnyder and 292Huwyler 2005b; Zhang et al. 2002) and polymeric nanoparticles (Reukov et al. 2932011a) can improve the performance of the chemical entities in the transport 294of therapeutic molecules across the BBB. Recent results suggest that low 295affinity binding and monovalent binding to the cellular receptors are highly 296effective for successful transcytosis (Niewoehner,et al., 2014; Yu et al. 2011).

297 In the development of photothermal therapy, gold nanoparticles 298conjugated to peptides carrying the motif THR target transferrin receptor (TfR) 299and they are delivered to the CNS (Prades et al. 2012b). Also, pegylated $300 \mathrm{Fe}_{3} \mathrm{O}_{4}$ nanoparticles conjugated with lactoferrin (Qiao et al. 2012b) have been 301 proposed as MRI molecular probes for imaging diagnostic purposes. In some 302instances, intravenously administered nanoparticles of different chemical 303origin get adsorbed to apolipoproteins and the entrance to the CNS is 304mediated by low density lipoprotein receptors (Gessner et al. 2001; Kim et al. 3052007). This is the case of human serum albumin nanoparticles (HSA) loaded 306with loperamide (Ulbrich et al. 2011a). Therefore, some nanoparticulate 307carriers have been modified to include low-density lipoproteins (LDL) or LDL 308receptor binding peptides (ApoB (Spencer and Verma 2007); APoE (Re et al. 3092011; Wagner et al. 2012) and Apo A-I (Fioravanti et al. 2012; Kratzer et al. 3102007a)) in their formulation, which results in significantly improved entrance to 311the brain parenchyma when compared with naked nanoparticles. In that 312 sense, HSA nanoparticles with covalently bound ApoA-I or ApoE are able to 313transport drugs to the brain with similar efficiency as HSA nanoparticles 314 conjugated to antibodies against insulin or transferrin receptors, or HSA 315nanoparticles conjugated to insulin or transferrin (Zensi et al. 2009; Zensi et 316al. 2010). Among successful examples, peptides derived from the consensus 317 binding sequence (Kunitz domain) of proteins transported through LDL 
318receptors, such as aprotinin and Kunitz precursor inhibitor 1 (Demeule et al. 3192008b; Gabathuler 2010b), must be stressed as very promising (Table 1). 320Kunitz-derived peptides (angiopeps), covalently bound to drugs, have been 321 already used or are in ongoing clinical trials for the treatment of brain tumors. 322The main objective of the targeting peptides in clinics is the treatment of brain 323 metastases from solid tumors (breast and lung cancers) as an alternative to 324the surgical removal of the primary brain tumor. Particularly, it has been 325demonstrated that angiopep conjugated to paclitaxel (ANG1005, also named 326GRN1005, http://clinicaltrials.gov/ct2/show/NCT01480583? 327 term=ANG1005\&rank $=6$ ), is well tolerated and shows activity in patients with 328 advanced solid tumors previously treated with antitumor drugs (Kurzrock et al. 3292012). In addition, there are three ongoing clinical trials in the same direction 330(http://clinicaltrials.gov). Apart from the endogenous ligands, other peptides 331 with high affinity for brain receptors (or strong cell-penetrating peptides) have 332also been explored as functional materials, including pegylated-gelatin 333siloxane nanoparticles conjugated with HIV-1-derived Tat peptide (Tian et al. 3342012), rabies virus glycoprotein conjugated to liposomes (Tao et al. 2012), 335variable heavy-chain domain of camel homodimeric antibodies (VHH) (Li et 336al., 2012) for receptor-homing peptides obtained from phage display 337screening (Maggie et al. 2010; Malcor et al. 2012). To gather all published 338information related to peptides with activity to cross the BBB, Van Dorpe and 339collaborators designed a peptide database to organize scattered information 340(Van et al. 2012) (http://brainpeps.ugent.be). The main approaches to protein341 guided BBB delivery of therapeutic nanoparticles are summarized in Figure 4. 342

\section{BBB-crossing for the treatment of CNS diseases.}

344 Among CNS diseases, only three are currently treated with drugs that 345naturally cross the BBB, namely epilepsy, chronic pain and psychiatric 346disorders (Ghose et al. 1999). For degenerative diseases, vascular diseases, 347 trauma aftermaths, viral infections and congenital diseases occurring in the $348 \mathrm{CNS}$, there is a pushing need to develop BBB-crossing strategies for drug 349delivery, preferentially based on non-viral carriers (Table 2). The most 350representative examples of how BBB-crossing is addressed in these 351 conditions are discussed in the next sections. 
3536.1. Neurodegenerative disorders

354 Therapeutic approaches to neurodegenerative diseases are 355 concentrating most of the efforts on the design of therapeutic compounds able 356to cross the BBB. For Parkinson's disease, the first drug used clinically was 357the dopamine precursor L-Dopa, that contrarily to dopamine itself, crosses the 358BBB by using a large amino acid transporter (Wade and Katzman 1975). On 359the other hand, in a Trojan Horse approach, Pardridge's group normalized 360 striatal tyrosine hydroxylase levels and reversed functional signs in a 361Parkinson model. A tyrosine hydroxylase gene empowered by a nervous 362system-specific promoter was injected, carried by pegylated liposomes 363decorated with OX26 antibody against TfR (Zhang et al. 2003; Zhang et al. 3642004a). The team was also successful entering erythropoietin (Zhou et al. 3652011b) and glial derived neurotrophic factor (GDNF) (Fu et al. 2010a) by 366joining these therapeutic proteins to mice anti-TfR antibodies, and 367 subsequently reaching clear neuroprotective effects.

368 Regarding Alzheimer, again, by means of this anti-TfR antibody as BBB 369 transporter and by fusion to an anti-Abeta amyloid antibody, the levels of beta 370amyloid peptide were dramatically reduced (Zhou et al. 2011a). In this 371 context, Genentech is developing a lower affinity variant of anti-TfR antibody 372(that favors release from the BBB towards the CNS) fused to an antibody 373against the enzyme BACE1, involved in amyloidal plaque formation. When the 374 bifunctional molecule is applied systemically, a decrease of $47 \%$ in plaques 375 was observed in mouse models ( $Y u$ et al. 2011). Interestingly, the fusion of a 376monovalent sFab of an anti-TfR antibody to an anti-Abeta antibody mediated 377 effective uptake transcytosisand TfR recycling, while the presence of two Fab 378 fragments onthe anti-Abeta antibody resulted in uptake followed by trafficking 379 to lysosomes and an associated reduction in TfR levels(Niewoehner et al, 3802014). This approach exhibited enhanced in vivo targeting of Abeta plaques 381after i.v. administration. Nerve growth factor (NGF) fused to an anti-TfR 382antibody has also been used successfully to prevent neuronal degeneration 383when applied intravenously in a Huntington disease model (Kordower et al. 3841994). In a similar context, a poly(mannitol-co-PEI) gene transporter modified 
385 with a rabies virus glycoprotein is able to ameliorates Alzheimer symptoms by 386transporting a therapeutic RNAi (Park, 2015). Alternatively, the intranasal 387route to the CNS (Hanson and Frey 2008), through the olfactory via and 388trigeminal nerve has been largely explored to introduce important factors in 389neurogenesis and memory such as NGF (De et al. 2005), insulin-like growth 390factor 1 (IGF- I) (Liu et al. 2004), fibroblast growth factor 2 (FGF-2) (Jin et al. 3912003), insulin (Benedict et al. 2004), interferon beta (IFN beta (Ross et al. 3922004) and the octapeptide NAP (Matsuoka et al. 2008) which is currently in 393Phase II clinical trials in patients with incipient Alzheimer 's disease (Gozes et 394al. 2009).

395

3966.2 Brain tumors

397 Diverse BBB-crossing anti-tumor vectors are under development in 398both pre-clinical and clinical phases, empowered by a spectrum of BBB399 crossing tags. Angiochem Inc. entered into Phase I clinical trials a product 400(ANG1005) that uses the peptide Angiopep-2, capable of driving the cargo 401paclitaxel by transcytosis through the BBB by using the LDL receptor LRP- 1 . 402This conjugate showed previously intracranial tumor regression in murine 403models when administered i.v. (Bichat 2008). Melanotransferrin associated 404with doxorubicin increased the survival in mice with intracranial tumors 405(Gabathuler 2005; Karkan et al. 2008). Albumin is being used at University of 406California, San Francisco (UCSF), in a Phase I clinical trial as a carrier of 407paclitaxel (nab- paclitaxel) to treat brain and CNS tumors (Chien et al. 2009) 408(it is already in the market for breast cancer). Targeting the transmembrane 409protein TMEM30A, the ligand FC5 (discovered by phage display, a single 410domain antibody - sdAb-), drives liposomes though the BBB to release 411doxorubicin into CNS (Gabathuler 2010a). On the other hand, by taking a 412Trojan Horse strategy based on pegylated immunoliposomes targeted to TfR 413(Boado et al. 2007), the delivery of shRNAs expression vectors against the 414epidermal growth factor receptor (EGFR) increased the survival in mice with 415intracranial tumors (Boado 2007; Pardridge 2004; Zhang et al. 2004b). 416Doxorubicin ferried by polysorbate-coated polymer nanoparticles promoted 417long-term glioblastoma remission in rats, probably by an unspecific BBB 418crossing (Steiniger et al. 2004), and a polycefin polymer variant that 
419specifically targets human brain, which associated to antiangiogenic 420oligonucleotides inhibits tumor angiogenesis and improves animal survival 421(Ljubimova et al. 2008).

422 On the other hand, despite no direct CNS targeting, it has been 423possible to increase the intracranial levels of anticancer 3'5'-dioctanoyl-5424fluoro-2'deoxyuridine (DO-FUdR), by incorporating it into a solid lipid 425nanoparticle (Wang et al. 2002). Furthermore, when administered 426systemically, nude phosphorothioate oligonucleotides against protein kinase $\mathrm{C}$ 427alpha, also reduced intracranial glioblastoma tumor size and doubled mice 428survival time (Yazaki et al. 1996). On the basis of these results, a phase II 429 clinical trial has been completed (http://www.clinicaltrials.gov/ct2/results? 430 term=pkc-alpha). In a more recent example, an intravenously injected cell 431penetrating peptide (LNP) decorating a polylysine-PEG gene vector extended 432the median survival time of glioma-bearing mice (Yao et al. 2014).

433

4346.3 Pain

435 Anti-nociception is usually achieved by methylation (Hansen, Jr. et al. 4361992) or glycosylation (Polt et al. 1994) of active molecules to stimulate their 437penetrability into the CNS. On the other hand, coupling human serum albumin 438to an anti-TfR permits the transport of loperamide into the CNS for anti439nociception effects (Ulbrich et al. 2009). The same drug is delivered into the $440 \mathrm{CNS}$ by injecting i.v. a poly(lactic-co-glycolic) acid (PLGA) nanoparticle, 441derivatized with the peptide $\mathrm{H}_{2} \mathrm{~N}-\mathrm{Gly}-\mathrm{L}-\mathrm{Phe}-\mathrm{D}-\mathrm{Thr}-\mathrm{Gly}-\mathrm{L}-\mathrm{Phe}-\mathrm{L}-\mathrm{Leu}-\mathrm{L}-\mathrm{Ser}(\mathrm{O}-\beta-$ 442D-Glucose)- $\mathrm{CONH}_{2}$ (g7) (Tosi et al. 2007). The analgesic dalargine joined to a 443 cationic cell-penetrating peptide (Syn-B) increases brain uptake in two orders 444of magnitude. This peptide crosses the BBB using a nonspecific route, that is, 445without association with a receptor (Rousselle et al. 2003). Other 446polyarginine-based peptides as CNS transporters are in preclinical phases 447(Gabathuler 2010a).

448

4496.4. Ischemia

450 Sequelae of cerebral ischemia can be lessened by CNS deliver of 451brain-derived neurotrophic factor (BDNF) (Wu and Pardridge 1999; Zhang 452and Pardridge 2001), fibroblast growth factor (FGF-2) (Song et al. 2002), 
453inhibitor of caspase-3 (Yemisci et al, 2014), vasoactive intestinal peptide (VIP) 454(Bickel et al. 1993; Wu and Pardridge 1996) and erythropoietin (EPO) (Fu et 455al. 2011) linked to an anti-TfR antibody. The nerve growth factor (NGF) gene 456has been introduced into the CNS while inside lipoplexes decorated with the 457TfR natural ligand, transferrin (da Cruz et al. 2005). The cell penetrating Tat 458peptide has also proven to carry efficiently $\mathrm{N}$-methyl D-aspartate receptor 459subtype 2B (NR2B) domain (Aarts et al. 2002), B-cell lymphoma-extra large 460protein $\left(\right.$ Bcl- $\left._{\mathrm{L}}\right)$ (Kilic et al. 2002), glial cell-derived neurotrophic factor (GDNF) 461(Kilic et al. 2003) and c-Jun domain (Borsello et al. 2003), to protect neurons 462in brain infarct models. On the other side, sniffing insulin-like growth factor 463(IGF-1) (Liu et al. 2004) and EPO (Yu et al. 2005) protects brain against 464stroke in animal models (Hanson and Frey 2008). Modular protein/DNA 465nanoparticles have been shown to induce biologically relevant transgenic 466protein levels and therapeutic effects after acute excytotoxic injuries when 467injected intracerebrally (Negro-Demontel,et al., 2014; Peluffo et al. 2003; 468Peluffo et al. 2006; Peluffo et al. 2011). The addition of CNS targeting 469domains to these particles may enable intravenous delivery retaining its 470neuroprotective potential.

\section{1}

\subsection{Infectious diseases}

473 CNS infectious diseases have also been treated in vivo using different 474approaches. By administering i.v. siRNA into Japanese encephalitis virus475infected mice, Manjunath and cols. afforded specific viral gene silencing and 476protection. The siRNA carrier was a two-domain peptide formed by nine 477arginines (R9) and a peptide derived from rabies virus glycoprotein (RVG) 478(Kumar et al. 2007). On the other hand, the brain levels of different anti HIV 479drugs have been increased several folds through association with liposomes 480(foscarnet, (Dusserre et al. 1995)), micelles (zidovudine, lamivudine, 481nelfinavir, (Spitzenberger et al. 2007)) and the Tat protein (ritonavir, (Rao et al. 4822009)). Furthermore, second stage African trypanosomiasis was treated 483intravenously in a mouse model by conjugating the active water-soluble drug 484to liposomes using polysorbate 80 as surfactant (Olbrich et al. 2002). 
Other diseases in which the BBB crossing has been successfully 488achieved are Hurler's Syndrome (mucopolysacharidosis), using the mouse 489anti-TfR antibody associated to a liposome with beta-glucuronidase gene 490 (Zhang et al. 2008) or fusioned to the alpha-L-iduronidase enzyme (Boado et 491al. 2008). A cell-penetrating Tat peptide improves the beta-glucuronidase 492biodistribution when organized as a single chain fusion protein (Xia et al. 4932001). Narcolepsy has also been treated with good results with nasal 494hypocretin I (Hanson and Lobner 2004).

495

496

4977. Administration routes

498 The intravenous administration of functionalized nanoparticles is the 499 most used therapeutic route. However, in some cases, patient compliance is 500 not easy to achieve, and alternative administration routes need to be 501 explored. In fact, there are standardized methods for drug delivery by osmotic 502disruption (Kroll and Neuwelt 1998; Yang et al. 2011), by local delivery placing 503polymer wafers after tumor excision (Balossier et al. 2010), by convection504enhanced delivery (White et al. 2012a; White et al. 2012b) or by intranasal 505administration (Grassin-Delyle et al. 2012; Tsai 2012; Wolf et al. 2012; Zhu et 506al. 2012) (Figure 1 A). Some of these treatments are still highly invasive and 507 are only addressed to high grade glioma patients. In the milder intranasal 508delivery, the drug is being accumulated in the olfactive bulb and then diffusing 509inside the brain. This approach has been proven to be quite effective in the 510 treatment of various disease models, acting through the olfactory pathway 511 and trigeminal nerve (Born et al. 2002; Hanson and Frey 2008). Regarding 512 gene therapy, only $1.9 \%$ of current clinical trials are performed on the CNS, 513and almost all of them are applied by intracranial injection or performed ex 514vivo (Ginn et al. 2013), pointing to the importance of the delivery of BBB515 crossing gene therapy vectors.

516

\section{Conclusions and future prospects}

518 Numerous examples of basic research and ongoing clinical trials illustrate 519 how proteins can be engineered to overcome the complexity of both BBB and 520BSCB in drug delivery contexts. In this regard, a few CNS diseases are 
521already treated with protein-based targeted drugs, and much more are 522expected to be released for use in the next future. Hopefully, and based on 523 current insights on the engineering of protein self-assembling, functional 524 proteins would be desirably adapted as building blocks of nanosized entities, 525acting at the same time as BBB crossers, targeting agents and drug carriers. 526Although the fully de novo design of such protein-based artificial viruses is in 527 its infancy, the accumulation of data about the physiology of the CNS and of 528 relevant cell receptors, the widening spectrum of drugs potentially useful in $529 \mathrm{CNS}$ therapies and the exploration of alternative routes for administration on 530the bases of result from the use of natural viruses envisage the generation of 531 these sophisticated vehicles as a forthcoming routine strategy.

\section{2}

\section{Acknowledgments}

534The authors acknowledge the financial support granted to H.P. and L.N. from 535Fundació Marató TV3, Catalunya, Spain, Comisión Sectorial de Investigación 536Científica de la Universidad de la República (CSIC-UDELAR), Uruguay, 537Agencia Nacional de Investigación e Innovación (ANII), Uruguay, FOCEM 538(MERCOSUR Structural Convergence Fund), COF 03/11, to E.V. from FIS 539(PI12/00327) and Fundació Marató TV3 (TV32013-133930) and to A.V. from 540Fundació Marató TV3 (TV32013-132031), MINECO (BIO2013-41019-P) and

541 from the Centro de Investigación Biomédica en Red (CIBER) de 542Bioingeniería, Biomateriales y Nanomedicina, with assistance from the 543European Regional Development Fund, for their nanomedical research . Z.X. 544and U.U. acknowledge financial support from China Scholarship Council and 545from ISCIII respectively, both through pre-doctoral fellowships. A.V. has been 546distinguished with an ICREA ACADEMIA award.

\section{7}

\section{Legends:}

549Figure 1. Anatomical basis of the BBB. Boundaries of the CNS tissue 550 contacting the blood vessels, meninges and the cerebrospinal fluid are 551 depicted (A), and also alternative routes for administration of substances to 552the CNS to bypass the BBB. The intimate relationship between ECs, 553 continuous basement membrane, astrocytes, pericytes and perivascular 554macrophages contributing to various degrees to the $\mathrm{BBB}$ formation and 
555maintenance can be observed (B). Moreover, ependimocytes of the choroid 556plexus produce the cerebrospinal fluid and conform, in addition, the Blood 557Cerebrospinal Fluid Barrier (BCFB) (C).

558

559Figure 2. Main barriers and transport mechanisms of the BBB. Physical 560 barriers as endothelial cell membranes or intercellular tight junctions are the 561 principal obstacles to overcome for polar macromolecules to enter the CNS 562(left). Moreover, intracellular and extracellular enzymes, basal membrane and 563 astrocyte endfeet can also constitute additional barriers. Endogenous protein 564 mediated selective transport mechanisms for small polar substances and 565 macromolecules are the responsible for the communication of the CNS with 566the blood flow (right). These can be exploited for targeted delivery of different 567 types of nanocomplexes.

\section{8}

569Figure 3. AAV9 administration routes and transduction efficiencies. Different 570results have been obtained when AAV9 where administered by i.v. or intra571 thecal delivery, but also in postnatal or adult animals, and importantly in mice 572or in non-human primates. While i.v. delivery efficiently transduce neurons and 573astrocytes in postnatal and adult mice, very low efficiency and mainly 574astrocyte transduction was observed in non-human primates. Moreover, 575intrathecal delivery into the Cisterna Magna resulted in the widest 576transduction in non-human primates.

\section{7}

578Figure 4. Receptor-mediated approaches used in Nanomedicine to cross the 579BBB. Different types of proteins (including antibodies) showing specific 580 binding to $\mathrm{BBB}$ transporters and cell surface receptors that are relevant to 581 transcytosis are used to functionalize nanoparticles (NPs). Cell-penetrating 582peptides carrying therapeutic proteins are also depicted. More details and 583 specific examples are given in Table 1.

584 
587

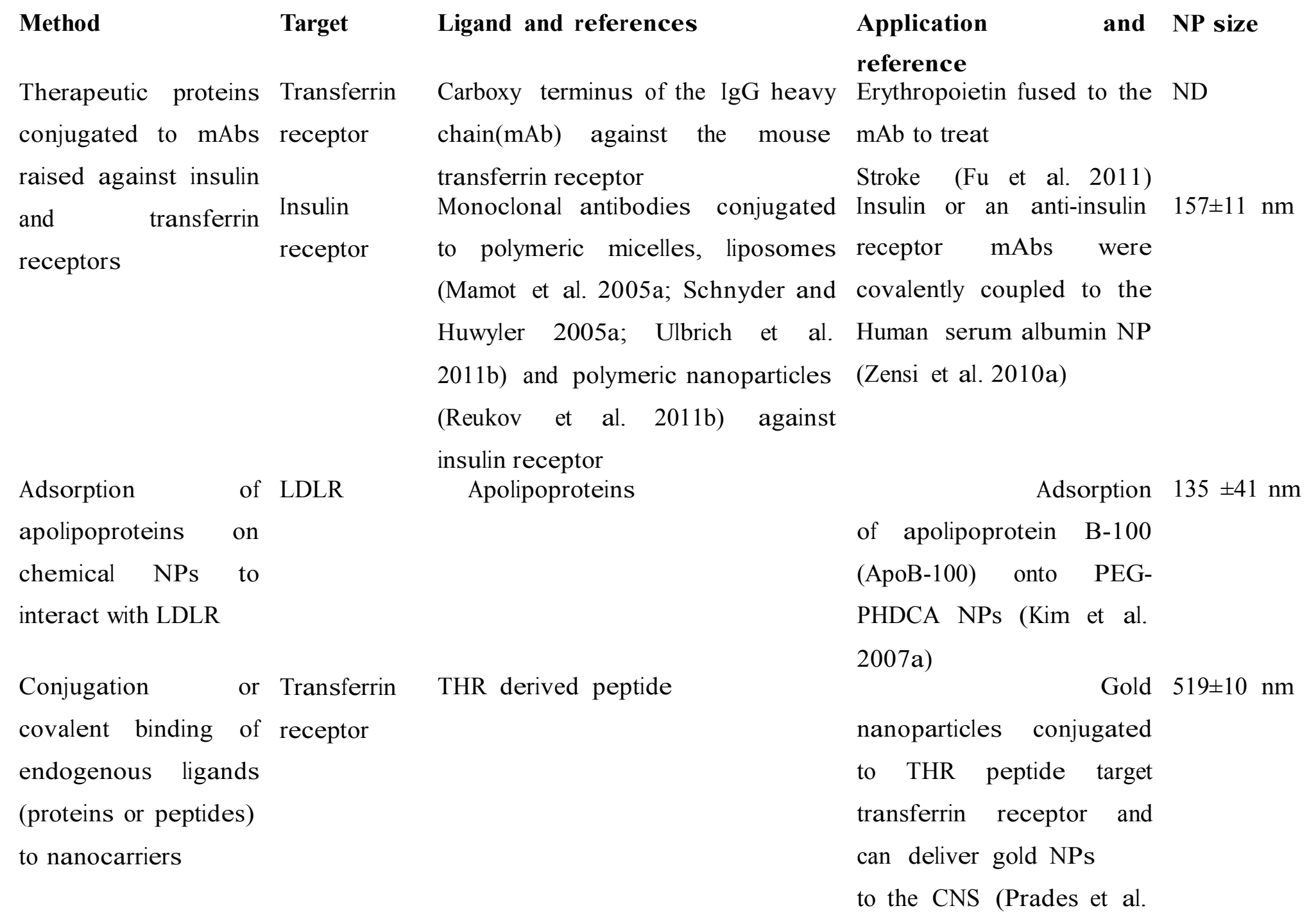


2012a)

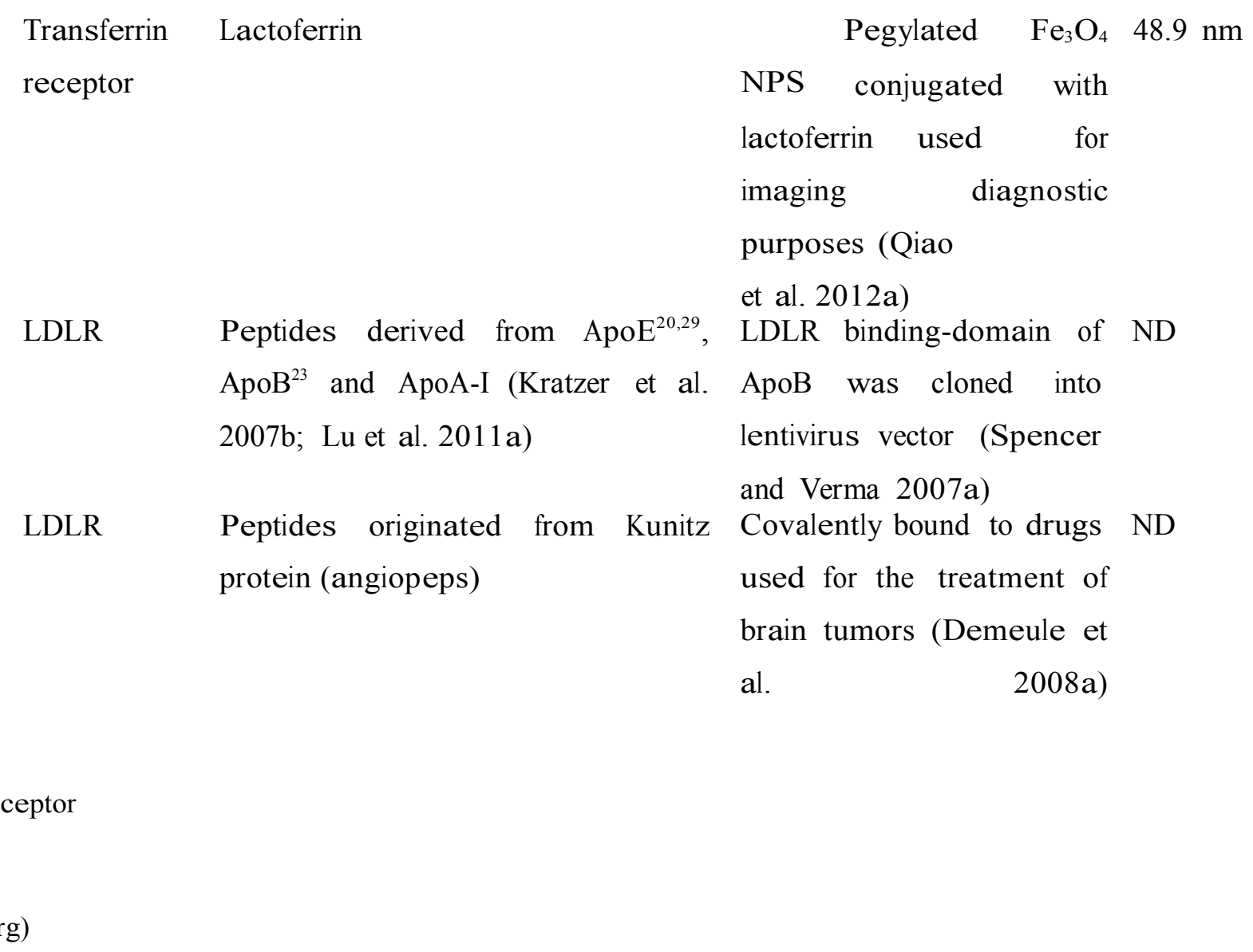

589mAbs: monoclonal antibodies

590LDLR: low density liproprotein receptor

591Apo: apolipoprotein

592NP: nanoparticle

593ND: not determined

594THR: tri-peptide motif (thre-his-arg) 
595Table 2: Disease-focused main approaches to BBB drug transdelivery.

\begin{tabular}{|c|c|c|c|c|}
\hline $\begin{array}{l}\text { Disease } \\
\text { Neurodegenerative }\end{array}$ & Drug & Target & Ligand and strategy & References \\
\hline \multirow{6}{*}{$\begin{array}{l}\text { disorders } \\
\text { Parkinson }\end{array}$} & & & & \\
\hline & L-Dopa & $\begin{array}{l}\text { Large amino acid } \\
\text { transporter }\end{array}$ & L-dopa & (Wade and Katzman 1975) \\
\hline & Tyrosine hydroxylase & & & \\
\hline & gene & TfR & $\begin{array}{l}\text { Pegylated liposome decorated with OX26 ab } \\
\text { agains TfR. }\end{array}$ & (Zhang et al. 2003; Zhang et al. 2 \\
\hline & Erythropoietin & $\mathrm{TfR}$ & Fusion protein joined to TfR ab. & (Zhou et al. 2011b) \\
\hline & GDNF & $\mathrm{TfR}$ & Fusion protein joined to $\mathrm{TfR}$ ab. & (Fu et al. $2010 b)$ \\
\hline \multirow[t]{2}{*}{ Alzheimer } & $\begin{array}{l}\mathrm{Ab} \text { against beta-amyloid } \\
\mathrm{Ab} \text { against } \mathrm{BACE} 1\end{array}$ & TfR & Fusion protein joined to TfR ab. & (Zhou et al. 2011a) \\
\hline & enzyme & TfR & Fusion protein joined to low affinity TfR ab. & (Yu et al. 2011) \\
\hline \multirow{3}{*}{$\begin{array}{l}\text { Huntinton disease } \\
\text { Brain tumors }\end{array}$} & NGF & TfR & Fusion protein joined to $\mathrm{TfR}$ ab. & (Kordower et al. 1994) \\
\hline & Antiangiogenic & ND & Polycefin polymer & (Ljubimova et al. 2008) \\
\hline & $\begin{array}{l}\text { oligonucleotides } \\
\text { DO-FUdR }\end{array}$ & $\begin{array}{l}\text { ND } \\
\text { LRP-1 (LDL }\end{array}$ & Drug incorporated in solid lipid nanoparticles & (Wang et al. 2002) \\
\hline \multirow[t]{5}{*}{ Intracranial tumor } & Paclitaxel & $\begin{array}{l}\text { receptor) } \\
\text { Melanotransferrin }\end{array}$ & Drug conjugated to Angiopep-2 peptide. & (Bichat 2008) \\
\hline & Paclitaxel & receptor & Drug associated with Melanotransferrin & (Karkan et al. 2008) \\
\hline & Paclitaxel & $\begin{array}{l}\text { ND } \\
\text { TMEM30A }\end{array}$ & Drug conjugated to Albumin & (Chien et al. 2009) \\
\hline & & transmembrane & & \\
\hline & Doxorubicin & protein & Liposomes decorated with FC5 ligand & (Gabathuler 2010a) \\
\hline
\end{tabular}


Insuline Receptor /

Transferrine Pegylated immunolyposomes associated to

shRNAs against EGFR receptor LDL receptor via

Doxorubicin

Oligonucleotides against

protein kinase $\mathrm{C}$ alpha $\mathrm{ND}$

Anti-nociception

Loperamide

Loperamide

Dalargine

Dalargine

\section{Cerebral isquemia}

$\begin{array}{ll}\text { BDNF } & \text { TfR } \\ \text { FGF-2 } & \text { TfR } \\ \text { VIP } & \text { TfR } \\ \text { Erythropoietin } & \text { TfR } \\ \text { NGF gene } & \text { TfR } \\ \text { NR2B } & \text { ND } \\ \text { Bcl-Xl } & \text { ND } \\ \text { GDNF } & \text { ND } \\ \text { JNKI } & \text { ND }\end{array}$

Infectious diseases
ApoB/E enrichment Drug bound to polysorbate-coated polymer

Nude oligonucleotide administration

Human serum albumin coupled to TfR ab.

Possible

adsorption-

mediated

endocytosis

ND

TMEM30A

transmembrane

protein

TfR
TfR
TfR
TfR
TfR
ND
ND
ND
ND

ND

PLGA nanoparticle derivatized with a glicosylated heptapeptide

Drug joined to cell penetrating peptides

Drug joined to a FC5-Fc fusion antibody

Protein linked to TfR ab.

Protein linked to TfR ab.

Protein linked to TfR ab.

Protein linked to TfR $\mathrm{ab}$.

Lipoplexes decorated with transferrin

Protein fused to cell penetrating peptide

Protein fused to cell penetrating peptide

Protein fused to cell penetrating peptide

Protein fused to cell penetrating peptide

9R-RVG fusion protein
(Boado 2007; Pardridge 2004)

(Steiniger et al. 2004)

(Yazaki et al. 1996)

(Ulbrich et al. 2009)

(Tosi et al. 2007)

(Rousselle et al. 2003)

(Farrington et al. 2014)
(Wu and Pardridge 1999)

(Song et al. 2002)

(Bickel et al. 1993)

(Fu et al. 2011)

(da Cruz et al. 2005)

(Aarts et al. 2002)

(Kilic et al. 2002)

(Kilic et al. 2003)

(Borsello et al. 2003)

(Kumar et al. 2007) 


$\begin{array}{ll}\text { Anti-VIH drugs } & \text { ND } \\ \text { Anti-VIH drugs } & \text { ND } \\ \text { Anti-VIH drugs } & \text { ND } \\ & \text { LDL receptor via } \\ & \end{array}$

\section{Mucopolysacharidosis}

\section{Diminazenediaceturate}

Beta-glucuronidase

gene

Alpha-L-iduronidase

\section{enzyme}

Beta-glucuronidase
Apo E enrichement
Drug associated to liposomes

Drug associated to micelles

Drug associated to cell penetrating peptide

Lipid-drug conjugate

Liposomes associated to TfR Ab.

Protein linked to TfR ab.

Protein fused to cell penetrating peptide
(Dusserre et al. 1995)

(Spitzenberger et al. 2007)

(Rao et al. 2009)

(Gessner et al. 2001)

(Zhang et al. 2008)

(Boado et al. 2008)

(Xia et al. 2001)

\section{ND: not determined}

597PLGA: Poly(lactic-co-glycolic) acid

598TfR: Transferrin receptor 
602Aarts,M., Y.Liu, L.Liu, S.Besshoh, M.Arundine, J.W.Gurd, Y.T.Wang, M.W.Salter, and 603 M.Tymianski. 2002. "Treatment of ischemic brain damage by perturbing NMDA 604 receptor- PSD-95 protein interactions." Science. 298:846-850.

605Abbott,N.J., L.Ronnback, and E.Hansson. 2006. "Astrocyte-endothelial interactions at 606 the blood-brain barrier." Nat.Rev.Neurosci. 7:41-53.

607Adinol,M. 1979. "The permeability of the blood-CSF barrier during foetal life 608 in man and rat and the effect of brain antibodies on the development of the 609 CNS." In Hemmings, editor, Protein transmission through living 610 membranes. Washington.

611Alvarez,J.I., A.Dodelet-Devillers, H.Kebir, I.Ifergan, P.J.Fabre, S.Terouz, M.Sabbagh, 612 K.Wosik, L.Bourbonniere, M.Bernard, H.J.van, H.E.de Vries, F.Charron, and 613 A.Prat. 2011. "The Hedgehog pathway promotes blood-brain barrier integrity 614 and CNS immune quiescence." Science. 334:1727-1731.

615Arthur,F.E., R.R.Shivers, and P.D.Bowman. 1987. "Astrocyte-mediated induction of 616 tight junctions in brain capillary endothelium: an efficient in vitro model." Brain 617 Res. 433:155-159.

618Balossier,A., L.Dorner, E.Emery, O.Heese, H.M.Mehdorn, P.Menei, and J.Singh. 619 2010. "Incorporating BCNU Wafers into Malignant Glioma Treatment 620 European Case Studies." 30:195-204.

621Bartanusz,V., D.Jezova, B.Alajajian, and M.Digicaylioglu. 2011. "The blood-spinal 622 cord barrier: morphology and clinical implications." Ann.Neurol. 70:194-206.

623Bechmann,I., J.Priller, A.Kovac, M.Bontert, T.Wehner, F.F.Klett, J.Bohsung, 624 M.Stuschke, U.Dirnagl, and R.Nitsch. 2001. "Immune surveillance of mouse 625 brain perivascular spaces by blood-borne macrophages." Eur.J.Neurosci. $626 \quad 14: 1651-1658$.

627Benedict,C., M.Hallschmid, A.Hatke, B.Schultes, H.L.Fehm, J.Born, and W.Kern. $628 \quad 2004$. "Intranasal insulin improves memory in humans."

629 Psychoneuroendocrinology. 29:1326-1334.

630Bhaskar,S., F.Tian, T.Stoeger, W.Kreyling, J.M.de la Fuente, V.Grazu, P.Borm, 631 G.Estrada, V.Ntziachristos, and D.Razansky. 2010. "Multifunctional 632 Nanocarriers for diagnostics, drug delivery and targeted treatment across 633 blood-brain barrier: perspectives on tracking and neuroimaging." Part $634 \quad$ Fibre.Toxicol. 7:3.

635Bichat,F.D.M.L.B.R.O.S.B.G.R.C.J.P.G.P. 2008. "Enhanced drug delivery to brain 636 tumours with a new paclitaxel-peptide conjugate." Eur.J.Cancer. Suppl. 6:139. 
637Bickel,U., T.Yoshikawa, E.M.Landaw, K.F.Faull, and W.M.Pardridge. 1993.

638 "Pharmacologic effects in vivo in brain by vector-mediated peptide drug

639 delivery." Proc.Natl.Acad.Sci.U.S.A. 90:2618-2622.

640Boado,R.J. 2007. "Blood-brain barrier transport of non-viral gene and RNAi

641 therapeutics." Pharm.Res. 24:1772-1787.

642Boado,R.J., Y.Zhang, Y.Zhang, and W.M.Pardridge. 2007. "Humanization of anti643 human insulin receptor antibody for drug targeting across the human blood-

644 brain barrier." Biotechnol.Bioeng. 96:381-391.

645Boado,R.J., Y.Zhang, Y.Zhang, C.F.Xia, Y.Wang, and W.M.Pardridge. 2008. "Genetic 646 engineering of a lysosomal enzyme fusion protein for targeted delivery across 647 the human blood-brain barrier." Biotechnol.Bioeng. 99:475-484.

648Born,J., T.Lange, W.Kern, G.P.McGregor, U.Bickel, and H.L.Fehm. 2002. "Sniffing 649 neuropeptides: a transnasal approach to the human brain." Nat.Neurosci. $650 \quad 5: 514-516$.

651Borsello,T., P.G.Clarke, L.Hirt, A.Vercelli, M.Repici, D.F.Schorderet, J.Bogousslavsky, 652 and C.Bonny. 2003. "A peptide inhibitor of c-Jun N-terminal kinase protects 653 against excitotoxicity and cerebral ischemia." Nat.Med. 9:1180-1186.

654Burger,C., K.Nash, and R.J.Mandel. 2005. "Recombinant adeno-associated viral 655 vectors in the nervous system." Hum. Gene Ther. 16:781-791.

656Chien,A.J., J.A.Illi, A.H.Ko, W.M.Korn, L.Fong, L.M.Chen, M.Kashani-Sabet, 657 C.J.Ryan, J.E.Rosenberg, S.Dubey, E.J.Small, T.M.Jahan, N.M.Hylton, 658 B.M.Yeh, Y.Huang, K.M.Koch, and M.M.Moasser. 2009. "A phase I study of a

659 2-day lapatinib chemosensitization pulse preceding nanoparticle albumin660 bound Paclitaxel for advanced solid malignancies." Clin.Cancer Res. 15:5569$661 \quad 5575$.

662Chodobski,A., B.J.Zink, and J.Szmydynger-Chodobska. 2011. "Blood-brain barrier 663 pathophysiology in traumatic brain injury." Transl.Stroke Res. 2:492-516.

664Corchero,J.L., B.Gasser, D.Resina, W.Smith, E.Parrilli, F.Vazquez, I.Abasolo, 665 M.Giuliani, J.Jantti, P.Ferrer, M.Saloheimo, D.Mattanovich, Schwartz S Jr, 666 L.Tutino, and A.Villaverde. 2013. "Unconventional microbial systems for the 667 cost-efficient production of high-quality protein therapeutics." Biotechnol.Adv. $668 \quad 31: 140-153$.

669da Cruz,M.T., A.L.Cardoso, L.P.de Almeida, S.Simoes, and M.C.de Lima. 2005. "Tf670 lipoplex-mediated NGF gene transfer to the CNS: neuronal protection and 671 recovery in an excitotoxic model of brain injury." Gene Ther. 12:1242-1252.

672Daya,S. and K.I.Berns. 2008. "Gene therapy using adeno-associated virus vectors." 673 Clin.Microbiol.Rev. 21:583-593. 
674De,R.R., A.A.Garcia, C.Braschi, S.Capsoni, L.Maffei, N.Berardi, and A.Cattaneo.

675 2005. "Intranasal administration of nerve growth factor (NGF) rescues

676 recognition memory deficits in AD11 anti-NGF transgenic mice."

677 Proc.Natl.Acad.Sci.U.S.A. 102:3811-3816.

678Deli,M.A., L.Descamps, M.P.Dehouck, R.Cecchelli, F.Joo, C.S.Abraham, and

679 G.Torpier. 1995. "Exposure of tumor necrosis factor-alpha to luminal

680 membrane of bovine brain capillary endothelial cells cocultured with astrocytes

681 induces a delayed increase of permeability and cytoplasmic stress fiber

682 formation of actin." J.Neurosci.Res. 41:717-726.

683Demeule,M., A.Regina, C.Che, J.Poirier, T.Nguyen, R.Gabathuler, J.P.Castaigne, and

684 R.Beliveau. 2008a. "Identification and design of peptides as a new drug

685 delivery system for the brain." Journal of Pharmacology and Experimental

686 Therapeutics. 324:1064-1072.

687Demeule,M., A.Regina, C.Che, J.Poirier, T.Nguyen, R.Gabathuler, J.P.Castaigne, and 688 R.Beliveau. 2008b. "Identification and design of peptides as a new drug

689 delivery system for the brain." 324:1064-1072.

690Didier,N., I.A.Romero, C.Creminon, A.Wijkhuisen, J.Grassi, and A.Mabondzo. 2003.

691 "Secretion of interleukin-1beta by astrocytes mediates endothelin-1 and

692 tumour necrosis factor-alpha effects on human brain microvascular endothelial

693 cell permeability." J.Neurochem. 86:246-254.

694Domingo-Espin,J., E.Vazquez, J.Ganz, O.Conchillo, E.Garcia-Fruitos, J.Cedano,

695 U.Unzueta, V.Petegnief, N.Gonzalez-Montalban, A.M.Planas, X.Daura,

696 H.Peluffo, N.Ferrer-Miralles, and A.Villaverde. 2011. "Nanoparticulate

697 architecture of protein-based artificial viruses is supported by protein-DNA

698 interactions." Nanomedicine (Lond). 6:1047-1061.

699Duque,S., B.Joussemet, C.Riviere, T.Marais, L.Dubreil, A.M.Douar, J.Fyfe, P.Moullier, 700 M.A.Colle, and M.Barkats. 2009. "Intravenous administration of self-

701 complementary AAV9 enables transgene delivery to adult motor neurons."

702 Mol.Ther. 17:1187-1196.

703Dusserre,N., C.Lessard, N.Paquette, S.Perron, L.Poulin, M.Tremblay, D.Beauchamp, 704 A.Desormeaux, and M.G.Bergeron. 1995. "Encapsulation of foscarnet in 705 liposomes modifies drug intracellular accumulation, in vitro anti-HIV-1 activity, 706 tissue distribution and pharmacokinetics." AIDS. 9:833-841.

707Edelstein,M.L., M.R.Abedi, and J.Wixon. 2007. "Gene therapy clinical trials worldwide 708 to 2007--an update." J.Gene Med. 9:833-842.

709Egleton,R.D. and T.P.Davis. 2005. "Development of neuropeptide drugs that cross 710 the blood-brain barrier." NeuroRx. 2:44-53. 
711el-Bacha,R.S. and A.Minn. 1999. "Drug metabolizing enzymes in cerebrovascular 712 endothelial cells afford a metabolic protection to the brain." Cell Mol.Biol. . $713 \quad 45: 15-23$.

714Farrington, G.K., N.Caram-Salas, A.S.Haqqani, E.Brunette, J.Eldredge, B.Pepinsky, 715 G.Antognetti, E.Baumann, W.Ding, E. Garber, S. Jiang, C.Delaney, E. Boileau, 716 W.P.Sisk, and D.B.Stanimirovic.2014. " A novel platform for engineering blood717 brain barrier-crossing bispecific biologics." FASEB J. 28:4764-

718 4778.Federici,T., J.S.Taub, G.R.Baum, S.J.Gray, J.C.Grieger, K.A.Matthews,

719 C.R.Handy, M.A.Passini, R.J.Samulski, and N.M.Boulis. 2012. "Robust spinal

720 motor neuron transduction following intrathecal delivery of AAV9 in pigs."

$721 \quad$ Gene Ther. 19:852-859.

722Ferrer-Miralles,N., E.Vazquez, and A.Villaverde. 2008. "Membrane-active peptides for 723 non-viral gene therapy: making the safest easier." Trends Biotechnol. 26:267724275 .

725Fioravanti,J., J.Medina-Echeverz, N.Ardaiz, C.Gomar, Z.P.Parra-Guillen, J.Prieto, 726 and P.Berraondo. 2012. "The Fusion Protein of IFN-alpha and Apolipoprotein 727 A-I Crosses the Blood-Brain Barrier by a Saturable Transport Mechanism." $728 \quad 188: 3988-3992$.

729Foust,K.D., E.Nurre, C.L.Montgomery, A.Hernandez, C.M.Chan, and B.K.Kaspar. 7302009 . "Intravascular AAV9 preferentially targets neonatal neurons and adult 731 astrocytes." Nat.Biotechnol. 27:59-65.

732Foust,K.D., X.Wang, V.L.McGovern, L.Braun, A.K.Bevan, A.M.Haidet, T.T.Le, 733 P.R.Morales, M.M.Rich, A.H.Burghes, and B.K.Kaspar. 2010. "Rescue of the 734 spinal muscular atrophy phenotype in a mouse model by early postnatal 735 delivery of SMN." Nat.Biotechnol. 28:271-274.

736Fu,A., Q.H.Zhou, E.K.Hui, J.Z.Lu, R.J.Boado, and W.M.Pardridge. 2010a.

737 "Intravenous treatment of experimental Parkinson's disease in the mouse with 738 an IgG-GDNF fusion protein that penetrates the blood-brain barrier." Brain 739 Res. 1352:208-213.

740Fu,A.L., E.K.W.Hui, J.Z.Lu, R.J.Boado, and W.M.Pardridge. 2011. "Neuroprotection 741 in stroke in the mouse with intravenous erythropoietin-Trojan horse fusion 742 protein." 1369:203-207.

743Fu,A.L., Q.H.Zhou, E.K.W.Hui, J.Z.Lu, R.J.Boado, and W.M.Pardridge. 2010 b.

744 "Intravenous treatment of experimental Parkinson's disease in the mouse with 745 an IgG-GDNF fusion protein that penetrates the blood-brain barrier."

$746 \quad 1352: 208-213$.

747Gabathuler,R. 2010a. "Approaches to transport therapeutic drugs across the blood$748 \quad$ brain barrier to treat brain diseases." Neurobiol.Dis. 37:48-57. 
749Gabathuler,R.A.G.K.M.L.C.Q.T.S.Y.J.s.W.V.T.Z.J.W.A. Development of a potential 750 protein vector(NeuroTrans) to deliver drugs across the blood-brain barrier. $751 \quad$ Int.Congr.Ser. 1277, 171-184. 2005.

752Gabathuler,R. 2010b. An Engineered Peptide Compound Platform Technology

753 Incorporating Angiopep for Crossing the BBB. HUMANA PRESS INC, 999

754 RIVERVIEW DR, STE 208, TOTOWA, NJ 07512-1165 USA.

755Gessner,A., C.Olbrich, W.Schroder, O.Kayser, and R.H.Muller. 2001. "The role of 756 plasma proteins in brain targeting: species dependent protein adsorption

757 patterns on brain-specific lipid drug conjugate (LDC) nanoparticles." 214:87-

75891.

759Ghose,A.K., V.N.Viswanadhan, and J.J.Wendoloski. 1999. "A knowledge-based 760 approach in designing combinatorial or medicinal chemistry libraries for drug 761 discovery. 1. A qualitative and quantitative characterization of known drug 762 databases." J.Comb.Chem. 1:55-68.

763Ginn,S.L., I.E.Alexander, M.L.Edelstein, M.R.Abedi, and J.Wixon. 2013. "Gene $764 \quad$ therapy clinical trials worldwide to 2." J.Gene Med. 15:65-77.

765Gozes,I., A.Stewart, B.Morimoto, A.Fox, K.Sutherland, and D.Schmeche. 2009.

$766 \quad$ "Addressing Alzheimer's disease tangles: from NAP to AL-108."

$767 \quad$ Curr.Alzheimer Res. 6:455-460.

768Grassin-Delyle,S., A.Buenestado, E.Naline, C.Faisy, S.Blouquit-Laye, L.J.Couderc, 769 M.Le Guen, M.Fischler, and P.Devillier. 2012. "Intranasal drug delivery: An 770 efficient and non-invasive route for systemic administration Focus on opioids." $771 \quad 134: 366-379$.

772Gray,S.J., B.L.Blake, H.E.Criswell, S.C.Nicolson, R.J.Samulski, T.J.McCown, and 773 W.Li. 2010. "Directed evolution of a novel adeno-associated virus (AAV) vector 774 that crosses the seizure-compromised blood-brain barrier (BBB)." Mol.Ther. $775 \quad 18: 570-578$.

776Gray,S.J., V.Matagne, L.Bachaboina, S.Yadav, S.R.Ojeda, and R.J.Samulski. 2011. 777 "Preclinical differences of intravascular AAV9 delivery to neurons and glia: a 778 comparative study of adult mice and nonhuman primates." Mol.Ther. 19:1058$779 \quad 1069$.

780Grieger,J.C. and R.J.Samulski. 2005. "Adeno-associated virus as a gene therapy 781 vector: vector development, production and clinical applications."

782 Adv.Biochem.Eng Biotechnol. 99:119-145.

783Hansen,D.W., Jr., A.Stapelfeld, M.A.Savage, M.Reichman, D.L.Hammond, 784 R.C.Haaseth, and H.I.Mosberg. 1992. "Systemic analgesic activity and delta785 opioid selectivity in [2,6-dimethyl-Tyr1,D-Pen2,D-Pen5]enkephalin."

$786 \quad$ J.Med.Chem. 35:684-687. 
787Hanson,L.R. and W.H.Frey. 2008. "Intranasal delivery bypasses the blood-brain 788 barrier to target therapeutic agents to the central nervous system and treat 789 neurodegenerative disease." BMC.Neurosci. 9 Suppl 3:S5.

790Hanson,M. and D.Lobner. 2004. "In vitro neuronal cytotoxicity of latex and nonlatex 791 orthodontic elastics." Am.J.Orthod.Dentofacial Orthop. 126:65-70.

792Iliff,J.J., M.Wang, Y.Liao, B.A.Plogg, W.Peng, G.A.Gundersen, H.Benveniste,

793 G.E.Vates, R.Deane, S.A.Goldman, E.A.Nagelhus, and M.Nedergaard. 2012.

794 "A paravascular pathway facilitates CSF flow through the brain parenchyma

795 and the clearance of interstitial solutes, including amyloid beta."

$796 \quad$ Sci.Transl.Med. 4:147ra111.

797Janzer,R.C. and M.C.Raff. 1987. "Astrocytes induce blood-brain barrier properties in $798 \quad$ endothelial cells." Nature. 325:253-257.

799Jin,K., L.Xie, J.Childs, Y.Sun, X.O.Mao, A.Logvinova, and D.A.Greenberg. 2003.

800 "Cerebral neurogenesis is induced by intranasal administration of growth

801 factors." Ann.Neurol. 53:405-409.

802Karkan,D., C.Pfeifer, T.Z.Vitalis, G.Arthur, M.Ujiie, Q.Chen, S.Tsai, G.Koliatis, 803 R.Gabathuler, and W.A.Jefferies. 2008. "A unique carrier for delivery of 804 therapeutic compounds beyond the blood-brain barrier." PLoS.One. 3:e2469.

805Kilic,E., G.P.Dietz, D.M.Hermann, and M.Bahr. 2002. "Intravenous TAT-Bcl-X1 is 806 protective after middle cerebral artery occlusion in mice." Ann.Neurol. 52:617$807 \quad 622$.

808Kilic,U., E.Kilic, G.P.Dietz, and M.Bahr. 2003. "Intravenous TAT-GDNF is protective 809 after focal cerebral ischemia in mice." Stroke. 34:1304-1310.

810Kim,H.R., K.Andrieux, S.Gil, M.Taverna, H.Chacun, D.Desmaele, F.Taran, D.Georgin, 811 and P.Couvreur. 2007. "Translocation of poly(ethylene glycol-co-

812 hexadecyl)cyanoacrylate nanoparticles into rat brain endothelial cells: role of

813 apolipoproteins in receptor-mediated endocytosis." Biomacromolecules.

814 8:793-799.

815Kim,W.K., X.Alvarez, J.Fisher, B.Bronfin, S.Westmoreland, J.McLaurin, and 816 K.Williams. 2006. "CD163 identifies perivascular macrophages in normal and 817 viral encephalitic brains and potential precursors to perivascular macrophages 818 in blood." Am.J.Pathol. 168:822-834.

819Kordower,J.H., V.Charles, R.Bayer, R.T.Bartus, S.Putney, L.R.Walus, and P.M.Friden. 820 1994. "Intravenous administration of a transferrin receptor antibody-nerve 821 growth factor conjugate prevents the degeneration of cholinergic striatal 822 neurons in a model of Huntington disease." Proc.Natl.Acad.Sci.U.S.A.

$82391: 9077-9080$.

824Kra tzer,I., K.Wernig, U.Panzenboeck, E.Bernhart, H.Reicher, R.Wronski, M.Win isch, 825 A.Hammer, E.Malle, A.Zimmer, and W.Sattler. 2007a. "Apolipoprotein A-I 
826 coating of protamine-oligonucleotide nanoparticles increases particle uptake 827 and transcytosis in an in vitro model of the blood-brain barrier." 117:301-311.

828Kratzer,I., K.Wernig, U.Panzenboeck, E.Bernhart, H.Reicher, R.Wronski, M.Windisch, 829 A.Hammer, E.Malle, A.Zimmer, and W.Sattler. 2007b. "Apolipoprotein A-I 830 coating of protamine-oligonucleotide nanoparticles increases particle uptake 831 and transcytosis in an in vitro model of the blood-brain barrier." J.Control $832 \quad$ Release. 117:301-311.

833Kroll,R.A. and E.A.Neuwelt. 1998. "Outwitting the blood-brain barrier for therapeutic 834 purposes: Osmotic opening and other means." 42:1083-1099.

835Kumar,P., H.Wu, J.L.McBride, K.E.Jung, M.H.Kim, B.L.Davidson, S.K.Lee, 836 P.Shankar, and N.Manjunath. 2007. "Transvascular delivery of small interfering 837 RNA to the central nervous system." Nature. 448:39-43.

838Kurzrock,R., N.Gabrail, C.Chandhasin, S.Moulder, C.Smith, A.Brenner, K.Sankhala, 839 A.Mita, K.Elian, D.Bouchard, and J.Sarantopoulos. 2012. "Safety,

840 Pharmacokinetics, and Activity of GRN1005, a Novel Conjugate of Angiopep-

841 2, a Peptide Facilitating Brain Penetration, and Paclitaxel, in Patients with

842 Advanced Solid Tumors." 11:308-316.

843Lee,S.Y., D.Mattanovich, and A.Villaverde. 2012. "Systems metabolic engineering, 844 industrial biotechnology and microbial cell factories." Microb. Cell Fact. 11:156.

845Li, T, JP. Bourgeois, S Celli, F. Glacial, AM. Le Sourd, S. Mecheri, S Mecheri, B. 846 Weksler, I. Romero, P.O. Couraud, F. Rougeon and P. Lafaye. (2012). "Cell847 penetrating anti-GFAP VHH and corresponding fluorescent fusion protein VHH848 GFP spontaneously cross the blood-brain barrier and specifically recognize 849 astrocytes: application to brain imaging." FASEB J 26:3969-3979.

850

851Liu,X.F., J.R.Fawcett, L.R.Hanson, and W.H.Frey. 2004. "The window of opportunity 852 for treatment of focal cerebral ischemic damage with noninvasive intranasal 853 insulin-like growth factor-I in rats." J.Stroke Cerebrovasc.Dis. 13:16-23.

854Ljubimova,J.Y., M.Fujita, A.V.Ljubimov, V.P.Torchilin, K.L.Black, and E.Holler. 2008.

855 "Poly(malic acid) nanoconjugates containing various antibodies and 856 oligonucleotides for multitargeting drug delivery." Nanomedicine.(Lond). 3:247857265.

858Lowenstein,P.R. 2009. "Crossing the rubicon." Nat.Biotechnol. 27:42-44.

859Lu,J.Z., R.J.Boado, E.K.Hui, Q.H.Zhou, and W.M.Pardridge. 2011. "Expression in $860 \mathrm{CHO}$ cells and pharmacokinetics and brain uptake in the Rhesus monkey of 861 an IgG-iduronate-2-sulfatase fusion protein." Biotechnol.Bioeng. 108:19548621964. 
863Maggie,J., L.Hsiang-Fa, C.Sing-Ming, K.Yi-Ju, and C.Li-Wen. Pepetide for

864 transmigration across brain blood barrier and delivery systems comprising the 865 same. 12/979, 804[US2011/0165079 A1]. 2010. US.

866Malcor,J.D., N.Payrot, M.David, A.Faucon, K.Abouzid, G.Jacquot, N.Floquet,

867 F.Debarbieux, G.Rougon, J.Martinez, M.Khrestchatisky, P.Vlieghe, and

868 V.Lisowski. 2012. "Chemical Optimization of New Ligands of the Low-Density

869 Lipoprotein Receptor as Potential Vectors for Central Nervous System

870 Targeting." 55:2227-2241.

871Mamot,C., D.C.Drummond, C.O.Noble, V.Kallab, Z.Guo, K.Hong, D.B.Kirpotin, and

872 J.W.Park. 2005. "Epidermal growth factor receptor-targeted immunoliposomes

873 significantly enhance the efficacy of multiple anticancer drugs in vivo." Cancer

874 Res.

65:11631-11638.

875Mandel,R.J., F.P.Manfredsson, K.D.Foust, A.Rising, S.Reimsnider, K.Nash, and 876 C.Burger. 2006. "Recombinant adeno-associated viral vectors as therapeutic 877 agents to treat neurological disorders." Mol.Ther. 13:463-483.

878Mastrobattista,E., M.A.van der Aa, W.E.Hennink, and D.J.Crommelin. 2006. "Artificial

879 viruses: a nanotechnological approach to gene delivery." Nat.Rev.Drug

880 Discov. 5:115-121.

881Matsuoka,Y., Y.Jouroukhin, A.J.Gray, L.Ma, C.Hirata-Fukae, H.F.Li, L.Feng,

882 L.Lecanu, B.R.Walker, E.Planel, O.Arancio, I.Gozes, and P.S.Aisen. 2008. "A

883 neuronal microtubule-interacting agent, NAPVSIPQ, reduces tau pathology

884 and enhances cognitive function in a mouse model of Alzheimer's disease."

$885 \quad$ J.Pharmacol.Exp.Ther. 325:146-153.

886McCown,T.J. 2005. "Adeno-associated virus (AAV) vectors in the CNS." Curr.Gene 887 Ther. 5:333-338.

888Niewoehner, J, B. Bohrmann, L. Collin, E. Urich, H. Sade, P. Maier, P. Rueger, J. O. 889 Stracke, W. Lau, A. C. Tissot, H. Loetscher, A. Ghosh, P-O. Freskgård. 2014.

890 "Increased brain penetration and potency of a therapeutic antibody using a

891 monovalent molecular shuttle". Neuron 81: 49-60.

892Negro-Demontel, ML, P. Saccardo, C. Giacomini,, R.J. Yáñez-Muñoz, N. Ferrer893 Miralles, E. Vazquez, A. Villaverde, H. Peluffo. 2014. "Comparative analysis of 894 lentiviral vectors and modular protein nanovectors for traumatic brain injury 895 gene therapy". Molecular Therapy - Methods \& Clinical Development 1: 14047.

896

897Neus Ferrer-Miralles, Escarlata Rodriguez-Carmona, Jose Luis Corchero, Elena 898 Garcia-Fruitos, Esther Vazquez, and Antonio Villaverde. 2013. "Engineering 899 protein self-assembling in protein-based nanomedicines for drug delivery and $900 \quad$ gene therapy." Crit Rev.Biotechnol. in press. 
901Olbrich,C., A.Gessner, O.Kayser, and R.H.Muller. 2002. "Lipid-drug-conjugate (LDC) 902 nanoparticles as novel carrier system for the hydrophilic antitrypanosomal 903 drug diminazenediaceturate." J.Drug Target. 10:387-396.

904Pardridge,W.M. 2004. "Intravenous, non-viral RNAi gene therapy of brain cancer." 905 Expert.Opin.Biol.Ther. 4:1103-1113.

906Pardridge,W.M. 2006. "Molecular Trojan horses for blood-brain barrier drug delivery." 907 Curr.Opin.Pharmacol. 6:494-500.

908Pardridge,W.M. and R.J.Boado. 2012. Reengineering Biopharmaceuticals for 909 Targeted Delivery Across the Blood-Brain Barrier. ELSEVIER ACADEMIC $910 \quad$ PRESS INC. SAN DIEGO.

911Park TE, Singh B, Li H, Lee JY, Kang SK, Choi YJ, Cho CS. 2015. " Enhanced BBB 912 permeability of osmotically active poly(mannitol-co-PEI) modified with rabies 913 virus glycoprotein via selective stimulation of caveolar endocytosis for RNAi 914 therapeutics in Alzheimer's disease." Biomaterials 38:61-71.

915Peluffo,H., L.Acarin, A.Aris, P.Gonzalez, A.Villaverde, B.Castellano, and B.Gonzalez. 9162006 . "Neuroprotection from NMDA excitotoxic lesion by $\mathrm{Cu} / \mathrm{Zn}$ superoxide 917 dismutase gene delivery to the postnatal rat brain by a modular protein 918 vector." BMC.Neurosci. 7:35.

919Peluffo,H., A.Aris, L.Acarin, B.Gonzalez, A.Villaverde, and B.Castellano. 2003. $920 \quad$ "Nonviral gene delivery to the central nervous system based on a novel 921 integrin-targeting multifunctional protein." Hum.Gene Ther. 14:1215-1223.

922Peluffo,H., D.li-Ruiz, A.Ejarque-Ortiz, V.Heras-Alvarez, E.Comas-Casellas, 923 A.Martinez-Barriocanal, A.Kamaid, D.varez-Errico, M.L.Negro, N.Lago, 924 J.S.Schwartz, A.Villaverde, and J.Sayos. 2011. "Overexpression of the 925 Immunoreceptor CD300f Has a Neuroprotective Role in a Model of Acute 926 Brain Injury." Brain Pathol.

927Poduslo,J.F. and G.L.Curran. 1992. "Increased permeability across the blood-nerve 928 barrier of albumin glycated in vitro and in vivo from patients with diabetic 929 polyneuropathy." Proc.Natl.Acad.Sci.U.S.A. 89:2218-2222.

930Polt,R., F.Porreca, L.Z.Szabo, E.J.Bilsky, P.Davis, T.J.Abbruscato, T.P.Davis, 931 R.Harvath, H.I.Yamamura, and V.J.Hruby. 1994. "Glycopeptide enkephalin 932 analogues produce analgesia in mice: evidence for penetration of the blood933 brain barrier." Proc.Natl.Acad.Sci.U.S.A. 91:7114-7118.

934Prades,R., S.Guerrero, E.Araya, C.Molina, E.Salas, E.Zurita, J.Selva, G.Egea, 935 C.Lopez-Iglesias, M.Teixido, M.J.Kogan, and E.Giralt. 2012a. "Delivery of gold 936 nanoparticles to the brain by conjugation with a peptide that recognizes the 937 transferrin receptor." Biomaterials. 33:7194-7205.

938Prades,R., S.Guerrero, E.Araya, C.Molina, E.Salas, E.Zurita, J.Selva, G.Egea, 939 C.Lopez-Iglesias, M.Teixido, M.J.Kogan, and E.Giralt. 2012b. "Delivery of gold 

transferrin receptor." 33:7194-7205.

942Qiao,R., Q.Jia, S.Huwel, R.Xia, T.Liu, F.Gao, H.J.Galla, and M.Gao. 2012 a.

943 "Receptor-mediated delivery of magnetic nanoparticles across the blood-brain 944 barrier." ACS Nano. 6:3304-3310.

945Qiao,R.R., Q.J.Jia, S.Huwel, R.Xia, T.Liu, F.B.Gao, H.J.Galla, and M.Y.Gao. 2012b. 946 "Receptor-Mediated Delivery of Magnetic Nanoparticles across the Blood947 Brain Barrier." 6:3304-3310.

948Rao,K.S., A.Ghorpade, and V.Labhasetwar. 2009. "Targeting anti-HIV drugs to the 949 CNS." Expert.Opin.Drug Deliv. 6:771-784.

950Re,F., I.Cambianica, S.Sesana, E.Salvati, A.Cagnotto, M.Salmona, P.O.Couraud, 951 S.M.Moghimi, M.Masserini, and G.Sancini. 2011. "Functionalization with 952 ApoE-derived peptides enhances the interaction with brain capillary 953 endothelial cells of nanoliposomes binding amyloid-beta peptide." 156:341954346.

955Reese,T.S. and M.J.Karnovsky. 1967. "Fine structural localization of a blood-brain 956 barrier to exogenous peroxidase." J.Cell Biol. 34:207-217.

957Reukov,V., V.Maximov, and A.Vertegel. 2011a. "Proteins Conjugated to Poly(Butyl 958 Cyanoacrylate) Nanoparticles as Potential Neuroprotective Agents." 108:243959252.

960Reukov,V., V.Maximov, and A.Vertegel. 2011b. "Proteins conjugated to poly(butyl 961 cyanoacrylate) nanoparticles as potential neuroprotective agents."

962 Biotechnol.Bioeng. 108:243-252.

963Rodriguez-Carmona,E. and A.Villaverde. 2010. "Nanostructured bacterial materials 964 for innovative medicines." Trends Microbiol. 18:423-430.

965Rosenberg,G.A. 2012. "Neurological diseases in relation to the blood-brain barrier." $966 \quad$ J.Cereb.Blood Flow Metab. 32:1139-1151.

967Ross,T.M., P.M.Martinez, J.C.Renner, R.G.Thorne, L.R.Hanson, and W.H.Frey. 2004. 968 "Intranasal administration of interferon beta bypasses the blood-brain barrier 969 to target the central nervous system and cervical lymph nodes: a non-invasive 970 treatment strategy for multiple sclerosis." J.Neuroimmunol. 151:66-77.

971Rousselle,C., P.Clair, M.Smirnova, Y.Kolesnikov, G.W.Pasternak, S.Gac-Breton, 972 A.R.Rees, J.M.Scherrmann, and J.Temsamani. 2003. "Improved brain uptake 973 and pharmacological activity of dalargin using a peptide-vector-mediated 974 strategy." J.Pharmacol.Exp.Ther. 306:371-376.

975Rubin,L.L. and J.M.Staddon. 1999. "The cell biology of the blood-brain barrier." $976 \quad$ Annu.Rev.Neurosci. 22:11-28. 
977Schnyder,A. and J.Huwyler. 2005a. "Drug transport to brain with targeted liposomes." $978 \quad$ NeuroRx. 2:99-107.

979Schnyder,A. and J.Huwyler. 2005b. "Drug transport to brain with targeted liposomes." $980 \quad 2: 99-107$.

981Song,B.W., H.V.Vinters, D.Wu, and W.M.Pardridge. 2002. "Enhanced neuroprotective 982 effects of basic fibroblast growth factor in regional brain ischemia after 983 conjugation to a blood-brain barrier delivery vector." J.Pharmacol.Exp.Ther.

$984 \quad 301: 605-610$.

985Spencer,B.J. and I.M.Verma. 2007. "Targeted delivery of proteins across the blood986 brain barrier." Proc.Natl.Acad.Sci.U.S.A. 104:7594-7599.

987Spitzenberger,T.J., D.Heilman, C.Diekmann, E.V.Batrakova, A.V.Kabanov, 988 H.E.Gendelman, W.F.Elmquist, and Y.Persidsky. 2007. "Novel delivery system 989 enhances efficacy of antiretroviral therapy in animal model for HIV-1

990 encephalitis." J.Cereb.Blood Flow Metab. 27:1033-1042.

991Steiniger,S.C., J.Kreuter, A.S.Khalansky, I.N.Skidan, A.I.Bobruskin, Z.S.Smirnova, 992 S.E.Severin, R.Uhl, M.Kock, K.D.Geiger, and S.E.Gelperina. 2004.

993 "Chemotherapy of glioblastoma in rats using doxorubicin-loaded

994 nanoparticles." Int.J.Cancer. 109:759-767.

995Stewart,P.A. and E.M.Hayakawa. 1987. "Interendothelial junctional changes underlie 996 the developmental 'tightening' of the blood-brain barrier." Brain Res. 429:271997281.

998Tao,Y.H., J.F.Han, and H.Y.Dou. 2012. "Brain-targeting gene delivery using a rabies 999 virus glycoprotein peptide modulated hollow liposome: bio-behavioral study." $1000 \quad 22: 11808-11815$.

1001Tian,X.H., F.Wei, T.X.Wang, D.Wang, J.Wang, X.N.Lin, P.Wang, and L.Ren. 2012. 1002 "Blood-brain barrier transport of Tat peptide and polyethylene glycol decorated 1003 gelatin-siloxane nanoparticle." 68:94-96.

1004Tonra,J.R. 2002. "Cerebellar susceptibility to experimental autoimmune 1005 encephalomyelitis in SJL/J mice: potential interaction of immunology with 1006 vascular anatomy." Cerebellum. 1:57-68.

1007Tosi,G., L.Costantino, F.Rivasi, B.Ruozi, E.Leo, A.V.Vergoni, R.Tacchi, A.Bertolini, 1008 M.A.Vandelli, and F.Forni. 2007. "Targeting the central nervous system: in vivo 1009 experiments with peptide-derivatized nanoparticles loaded with Loperamide 1010 and Rhodamine-123." J.Control Release. 122:1-9.

1011Towne,C., C.Raoul, B.L.Schneider, and P.Aebischer. 2008. "Systemic AAV6 delivery 1012 mediating RNA interference against SOD1: neuromuscular transduction does 1013 not alter disease progression in fALS mice." Mol.Ther. 16:1018-1025. 
1014Tsai,S.J. 2012. "Peripheral administration of brain-derived neurotrophic factor to Rett 1015

1016 syndrome animal model: A possible approach for the treatment of Rett syndrome." 18:HY33-HY36.

1017Ulbrich,K., T.Hekmatara, E.Herbert, and J.Kreuter. 2009. "Transferrin- and transferrin1018 receptor-antibody-modified nanoparticles enable drug delivery across the 1019 blood-brain barrier (BBB)." Eur.J.Pharm.Biopharm. 71:251-256.

1020Ulbrich,K., T.Knobloch, and J.Kreuter. 2011a. "Targeting the insulin receptor: 1021 nanoparticles for drug delivery across the blood-brain barrier (BBB)." 19:1251022132.

1023Ulbrich,K., T.Knobloch, and J.Kreuter. 2011. "Targeting the insulin receptor: 1024 nanoparticles for drug delivery across the blood-brain barrier (BBB)." J.Drug 1025 Target. 19:125-132.

1026Unzueta,U., M.V.Cespedes, N.Ferrer-Miralles, I.Casanova, Cedano JA, Corchero JL, 1027 J.Domingo-Espin, Villaverde A, R.Mangues, and Vazquez E. 2012a. 1028 "Intracellular $\mathrm{CXCR}^{+}$cell targeting with T22-empowered protein-only 1029 nanoparticles." Int.J.Nanomedicine. 7:4533-4544.

1030Unzueta,U., N.Ferrer-Miralles, J.Cedano, X.Zikung, M.Pesarrodona, P.Saccardo, 1031 E.Garcia-Fruitos, J.Domingo-Espin, P.Kumar, K.C.Gupta, R.Mangues, 1032 A.Villaverde, and E.Vazquez. 2012b. "Non-amyloidogenic peptide tags for the 1033 regulatable self-assembling of protein-only nanoparticles." Biomaterials. $1034 \quad 33: 8714-8722$.

1035Unzueta,U., P.Saccardo, J.Domingo-Espin, J.Cedano, O.Conchillo-Sole, E.Garcia1036 Fruitos, M.V.Cespedes, J.L.Corchero, X.Daura, R.Mangues, N.Ferrer-Miralles, 1037 A.Villaverde, and E.Vazquez. 2013. "Sheltering DNA in self-organizing, 1038 protein-only nano-shells as artificial viruses for gene delivery." Nanomedicine.

1039Van,D.S., A.Bronselaer, J.Nielandt, S.Stalmans, E.Wynendaele, K.Audenaert, C.Van 1040 De Wiele, C.Burvenich, K.Peremans, H.Hsuchou, T.G.De, and S.B.De. 2012. 1041 "Brainpeps: the blood-brain barrier peptide database." Brain Struct.Funct. $1042 \quad$ 217:687-718.

1043Vazquez,E., N.Ferrer-Miralles, R.Mangues, J.L.Corchero, Schwartz S Jr, and 1044 A.Villaverde. 2009. "Modular protein engineering in emerging cancer 1045 therapies." Curr.Pharm.Des. 15:893-916.

1046Vazquez,E., N.Ferrer-Miralles, and A.Villaverde. 2008. "Peptide-assisted traffic 1047 engineering for nonviral gene therapy." Drug Discov.Today. 13:1067-1074.

1048Vazquez,E., M.Roldan, C.Diez-Gil, U.Unzueta, J.Domingo-Espin, J.Cedano, 1049 O.Conchillo, I.Ratera, J.Veciana, X.Daura, N.Ferrer-Miralles, and A.Villaverde. 1050 2010. "Protein nanodisk assembling and intracellular trafficking powered by an 1051 arginine-rich (R9) peptide." Nanomedicine.(Lond). 5:259-268. 
1052Vazquez,E. and A.Villaverde. 2010. "Engineering building blocks for self-assembling 1053 protein nanoparticles." Microb. Cell Fact. 9:101.

1054Vazquez,E. and A.Villaverde. 2013. "Microbial biofabrication for nanomedicine: 1055 biomaterials, nanoparticles and beyond." Nanomedicine (Lond). 8:1895-1898.

1056Wade,L.A. and R.Katzman. 1975. "Synthetic amino acids and the nature of L-DOPA 1057 transport at the blood-brain barrier." J.Neurochem. 25:837-842.

1058Wagner,S., A.Zensi, S.L.Wien, S.E.Tschickardt, W.Maier, T.Vogel, F.Worek, 1059 C.U.Pietrzik, J.Kreuter, and H.von Briesen. 2012. "Uptake Mechanism of 1060 ApoE-Modified Nanoparticles on Brain Capillary Endothelial Cells as a Blood1061 Brain Barrier Model." 7.

1062Wang,J.X., X.Sun, and Z.R.Zhang. 2002. "Enhanced brain targeting by synthesis of 1063 3',5'-dioctanoyl-5-fluoro-2'-deoxyuridine and incorporation into solid lipid 1064 nanoparticles." Eur.J.Pharm.Biopharm. 54:285-290.

1065White,E., A.Bienemann, J.Pugh, E.Castrique, M.Wyatt, H.Taylor, A.Cox, C.Mcleod, 1066 and S.Gill. 2012a. "An evaluation of the safety and feasibility of convection1067 enhanced delivery of carboplatin into the white matter as a potential treatment 1068 for high-grade glioma." 108:77-88.

1069White,E., A.Bienemann, H.Taylor, K.Hopkins, A.Cameron, and S.Gill. 2012b. "A 1070 phase I trial of carboplatin administered by convection-enhanced delivery to 1071 patients with recurrent/progressive glioblastoma multiforme." 33:320-331.

1072Witt,K.A., J.D.Huber, R.D.Egleton, M.J.Roberts, M.D.Bentley, L.Guo, H.Wei, 1073 H.I.Yamamura, and T.P.Davis. 2001. "Pharmacodynamic and pharmacokinetic 1074 characterization of poly(ethylene glycol) conjugation to met-enkephalin analog 1075 [D-Pen2, D-Pen5]-enkephalin (DPDPE)." J.Pharmacol.Exp.Ther. 298:848-856.

1076Wolburg,H. and A.Lippoldt. 2002. "Tight junctions of the blood-brain barrier:

1077 development, composition and regulation." Vascul.Pharmacol. 38:323-337.

1078Wolf,D.A., L.R.Hanson, E.L.Aronovich, Z.Nan, W.C.Low, W.H.Frey, and R.McIvor. 1079 2012. "Lysosomal enzyme can bypass the blood-brain barrier and reach the 1080 CNS following intranasal administration." 106:131-134.

1081Wu,D. and W.M.Pardridge. 1996. "Central nervous system pharmacologic effect in 1082 conscious rats after intravenous injection of a biotinylated vasoactive intestinal 1083 peptide analog coupled to a blood-brain barrier drug delivery system." 1084 J.Pharmacol.Exp.Ther. 279:77-83.

1085Wu,D. and W.M.Pardridge. 1999. "Neuroprotection with noninvasive neurotrophin 1086 delivery to the brain." Proc.Natl.Acad.Sci.U.S.A. 96:254-259.

1087Xia,H., Q.Mao, and B.L.Davidson. 2001. "The HIV Tat protein transduction domain 1088 improves the biodistribution of beta-glucuronidase expressed from 1089 recombinant viral vectors." Nat.Biotechnol. 19:640-644. 
1090Yang,W.L., T.Y.Huo, R.F.Barth, N.Gupta, M.Weldon, J.C.Grecula, B.D.Ross, B.A.Hoff, 1091 T.C.Chou, J.Rousseau, and H.Elleaume. 2011. "Convection enhanced delivery 1092 of carboplatin in combination with radiotherapy for the treatment of brain 1093 tumors." 101:379-390.

1094 Yao H., K. Wang, Y. Wang, S. Wang, J. Li, J. Lou , L. Ye , X. Yan ,W. Lu ,R. Huang. 1095 2014. "Enhanced blood-brain barrier penetration and glioma therapy mediated 1096 by a new peptide modified gene delivery system." Biomaterials. 2014 1097 37C:345-352. Yazaki,T., S.Ahmad, A.Chahlavi, E.Zylber-Katz, N.M.Dean, 1098 S.D.Rabkin, R.L.Martuza, and R.I.Glazer. 1996. "Treatment of glioblastoma U109987 by systemic administration of an antisense protein kinase C-alpha 1100 phosphorothioate oligodeoxynucleotide." Mol.Pharmacol. 50:236-242.

1101Yemisci, M., S. Caban, Y.Gursoy-Ozdemir, S.Lule, R.Novoa-Carballal, R.Riguera, 1102 E.Fernandez-Megia, K. Andrieux, P.Couvreur, Y.Capan, T. Dalkara. 2014. 1103 "Systemically administered brain-targeted nanoparticles transport peptides 1104 across the blood-brain barrier and provide neuroprotection." J Cereb Blood 1105 Flow Metab. doi: 10.1038/jcbfm.2014.220. [Epub ahead of print]

1106Yu,Y.J., Y.Zhang, M.Kenrick, K.Hoyte, W.Luk, Y.Lu, J.Atwal, J.M.Elliott, S.Prabhu, 1107 R.J.Watts, and M.S.Dennis. 2011. "Boosting brain uptake of a therapeutic 1108 antibody by reducing its affinity for a transcytosis target." Sci.Transl.Med. $1109 \quad 3: 84 \mathrm{ra} 44$.

1110Yu,Y.P., Q.Q.Xu, Q.Zhang, W.P.Zhang, L.H.Zhang, and E.Q.Wei. 2005. "Intranasal 1111 recombinant human erythropoietin protects rats against focal cerebral 1112 ischemia." Neurosci.Lett. 387:5-10.

1113Yue,J., S.Liu, R.Wang, X.Hu, Z.Xie, Y.Huang, and X.Jing. 2012. "Fluorescence1114 Labeled Immunomicelles: Preparation, in vivo Biodistribution, and Ability to 1115 Cross the Blood-Brain Barrier." 12:1209-1219.

1116Zensi,A., D.Begley, C.Pontikis, C.Legros, L.Mihoreanu, C.Buchel, and J.Kreuter. 1117 2010. "Human serum albumin nanoparticles modified with apolipoprotein A-I 1118 cross the blood-brain barrier and enter the rodent brain." J.Drug Target. $1119 \quad 18: 842-848$.

1120Zensi,A., D.Begley, C.Pontikis, C.Legros, L.Mihoreanu, S.Wagner, C.Buechel, H.von 1121 Briesen, and J.Kreuter. 2009. "Albumin nanoparticles targeted with Apo E 1122 enter the CNS by transcytosis and are delivered to neurones." 137:78-86.

1123Zhang,Y., F.Calon, C.Zhu, R.J.Boado, and W.M.Pardridge. 2003. "Intravenous 1124 1125 1126 nonviral gene therapy causes normalization of striatal tyrosine hydroxylase and reversal of motor impairment in experimental parkinsonism." Hum.Gene Ther. 14:1-12.

1127Zhang,Y., H.J.Lee, R.J.Boado, and W.M.Pardridge. 2002. "Receptor-mediated 1128 delivery of an antisense gene to human brain cancer cells." 4:183-194. 
1129Zhang,Y. and W.M.Pardridge. 2001. "Neuroprotection in transient focal brain 1130 ischemia after delayed intravenous administration of brain-derived 1131 neurotrophic factor conjugated to a blood-brain barrier drug targeting system." $1132 \quad$ Stroke. 32:1378-1384.

1133Zhang,Y., F.Schlachetzki, Y.F.Zhang, R.J.Boado, and W.M.Pardridge. 2004a. 1134 "Normalization of striatal tyrosine hydroxylase and reversal of motor 1135 impairment in experimental parkinsonism with intravenous nonviral gene 1136 therapy and a brain-specific promoter." Hum.Gene Ther. 15:339-350.

1137Zhang,Y., Y.Wang, R.J.Boado, and W.M.Pardridge. 2008. "Lysosomal enzyme 1138 replacement of the brain with intravenous non-viral gene transfer." 1139 Pharm.Res. 25:400-406.

1140Zhang,Y., Y.F.Zhang, J.Bryant, A.Charles, R.J.Boado, and W.M.Pardridge. 2004b. 1141 "Intravenous RNA interference gene therapy targeting the human epidermal 1142 growth factor receptor prolongs survival in intracranial brain cancer." $1143 \quad$ Clin.Cancer Res. 10:3667-3677.

1144Zhou,Q.H., A.Fu, R.J.Boado, E.K.Hui, J.Z.Lu, and W.M.Pardridge. 2011a. "Receptor1145 mediated abeta amyloid antibody targeting to Alzheimer's disease mouse 1146 brain." Mol.Pharm. 8:280-285.

1147Zhou,Q.H., E.K.Hui, J.Z.Lu, R.J.Boado, and W.M.Pardridge. 2011 b. "Brain 1148

1149

1150 penetrating IgG-erythropoietin fusion protein is neuroprotective following intravenous treatment in Parkinson's disease in the mouse." Brain Res. 1382:315-320.

1151Zhu,J.H., Y.J.Jiang, G.L.Xu, and X.F.Liu. 2012. "Intranasal administration: a potential 1152

1153

1154

1155

1156 